\title{
Last stage of Variscan granitoid magmatism in the Strzelin Massif (SW Poland): petrology and age of the biotite-muscovite granites
}

\author{
Teresa OBERC-DZIEDZIC ${ }^{1, *}$, Ryszard KRYZA ${ }^{1}$ and Christian PIN $^{2}$ \\ 1 University of Wrocław, Institute of Geological Sciences, Plac M. Borna 9, 50-204 Wrocław, Poland \\ 2 Université Blaise Pascal, Département de Géologie, CNRS, 5 rue Kessler, 63038 Clermont-Ferrand, Cedex, France
}

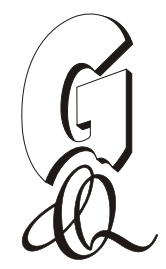

\begin{abstract}
Oberc-Dziedzic, T., Kryza, R., Pin, Ch., 2015. Last stage of Variscan granitoid magmatism in the Strzelin Massif (SW Poland): petrology and age of the biotite-muscovite granites. Geological Quarterly, 59 (4): 718-737, doi: 10.7306/gq.1248

New petrographic and geochemical data show some differences between Variscan Bt-Ms granites occurring either as small plutons or dykes in the Strzelin Massif (SW Poland). The granites of the Gromnik and Górka Sobocka plutons are rich in micas and crystallised from "wet" magmas; the granites of the dykes and the Gębczyce Pluton are mica-poorer and cordierite-bearing rocks derived from "dryer" magmas. The lower initial $\varepsilon \mathrm{Nd}=-5.4$ to -5.9 values in the Bt-Ms granites of the dykes, compared with those in the plutons $(\varepsilon \mathrm{Nd}=-4.5$ to -4.9$)$, reflect a more "crustal" signature of the former, possibly due to local crustal assimilation, via AFC, shortly before emplacement. Much more radiogenic initial ${ }^{87} \mathrm{Sr} /{ }^{86} \mathrm{Sr}$ ratios in the dykes, up to 0.726 , further suggest the involvement of extraneous, hydrous crustal fluids enriched in ${ }^{87} \mathrm{Sr}$ during the evolution of late-stage magma derivatives. The new U-Pb SHRIMP zircon age of $296 \pm 6 \mathrm{Ma}$ for the Gebczyce Bt-Ms granite shows that this body belongs to the third stage of magmatism in the Strzelin Massif. The U-Pb SHRIMP zircon data for the Bt-Ms granite dykes provide ages similar to those of their host rocks: c. $295 \mathrm{Ma}$ for the Gęsiniec tonalite and the enclosed Bt-Ms granite, and c. $285 \mathrm{Ma}$ for the Strzelin biotite granite and its Bt-Ms granite dykes. These new data from peraluminous rock-types complement our previous studies focused on the tonalites, granodiorites and biotite granites, and shed light on the late-stage igneous evolution of the Strzelin Massif.
\end{abstract}

Key words: biotite-muscovite granite, cordierite nodules, SHRIMP zircon ages, Variscan granitoids, Strzelin Massif.

\section{INTRODUCTION}

The Sudetes (Fig. 1A), located in the northeastern termination of the Variscan Orogen in Europe, are composed of fragments of two crustal blocks: the West and Cental Sudetes that belong to the Bohemian Massif, and the East Sudetes being a part of the Brunovistulicum segment. The Sudetes abound in granitoids which differ in age and composition.

The oldest granitoids, c. 350-330 Ma in age, occur in the Central Sudetes. They are represented by shear zones-related hornblende-bearing granodiorites, tonalites, diorites and granites. Similar granitoids occur in the Middle Odra Fault Zone, north of the Sudetes (Oberc-Dziedzic et al., 2015 and references therein).

The granitoids of the West Sudetes are, in general, younger than those of the Central Sudetes. They form two large granite plutons: the Karkonosze Pluton and the Strzegom-Sobótka Pluton. The granitoids of the Karkonosze Pluton were dated by the ID-TIMS method at $312 \mathrm{Ma}$ (Kryza et al., 2014a); the earlier reported SIMS (SHRIMP) zircon data are scattered mainly be-

* Corresponding author, e-mail: teresa.oberc-dziedzic@ing.uni.wroc.pl Received: June 18, 2015; accepted: July 21, 2015; first published online: September 09, 2015 tween c. 322 and 302 (e.g., Kryza et al., 2012, 2014b). Similar dates of 320-317 Ma were obtained by Žák et al. (2013) by the LA-ICP-MS method. The granitoids of the Strzegom-Sobótka were emplaced in the 305-295 Ma time span (SHRIMP U-Pb zircon data; Turniak et al., 2014).

Granitoids of the East Sudetes domain crop out in the Strzelin Massif (Fig. 1), but also occur east of this massif, beneath a cover of Cenozoic sediments. They form small intrusions of granites, tonalites and quartz diorites. These granitoids were dated by various techniques at 324-283 Ma (Turniak et al., 2006; Pietranik and Waight, 2008; Oberc-Dziedzic et al., 2010a, 2013; Oberc-Dziedzic and Kryza, 2012). South of the Strzelin Massif, the Variscan granitoids form the relatively large Žulová Pluton (c. 292 Ma, LA-ICP-MS U-Pb zircon age; Laurent et al., 2014).

Two-mica (Bt-Ms) granites are relatively scarce in the West and Central Sudetes, where they form the oldest, subordinate parts of the Karkonosze and the Strzegom-Sobótka plutons. The Bt-Ms Tanvald granite in the Karkonosze Pluton was dated at $317 \pm 2 \mathrm{Ma}$ (Žák et al., 2013), while the two-mica granite in the Strzegom-Sobótka Pluton crystallised at $305 \pm 3 \mathrm{Ma}$ (SHRIMP U-Pb zircon data; Turniak et al., 2014). In the Central Sudetes, the Bt-Ms granites are represented by a variety of the Jawornik granitoids dated at $336 \pm 2 \mathrm{Ma}$ (SHRIMP U-Pb zircon data; Białek, 2014).

In comparison with the West and Central Sudetes, the Bt-Ms granites are relatively common in the Strzelin Massif, in 


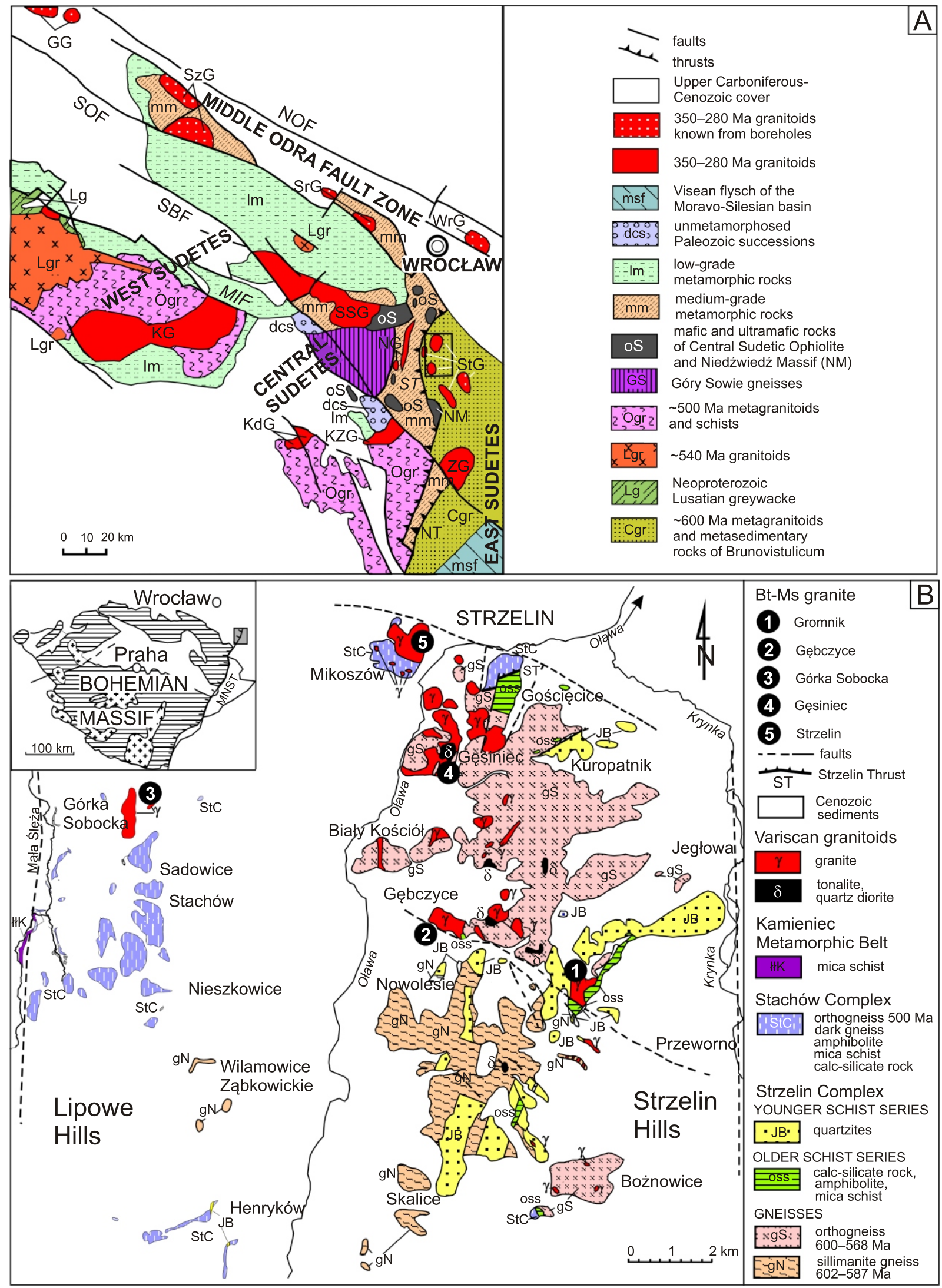

Fig. 1. Geological position of the Strzelin Massif

A - granitoids of the Sudetes, Fore-Sudetic Block and Odra Fault Zone; Odra Fault Zone: GG - Gubin, SrG - Środa Śląska, SzG Szprotawa, WrG - Wrocław; Fore-Sudetic Block: NG - Niemcza, SSG - Strzegom-Sobótka, StG - Strzelin, ZG - Žulova; Sudetes: KdG Kudowa, KG - Karkonosze, KZG - Kłodzko-Złoty Stok; faults: MIF - Main Intra-Sudetic Fault, SBF - Sudetic Boundary Fault, SOF - Southern Odra Fault, NOF - Northern Odra Fault; thrusts: NT - Nyznerov Thrust, ST - Strzelin Thrust (separating the Stachów and Strzelin complexes); rectangle shows the position of the Strzelin Massif; B - geological map of the Strzelin Massif (compiled by Oberc-Dziedzic and Madej, 2002; based on Wójcik, 1968; Wroński, 1973; Badura, 1979; Oberc et al., 1988); inlet - sketch map of the Bohemian Massif (MNST Moldanubian-Nyznerov-Strzelin Thrust separating the Bohemian Massif from Brunovistulicum); grey rectangle shows the position of the Strzelin Massif 
the northern prolongation of the East Sudetes, where they form small plutons and dykes. In this contribution, we present petrographic, geochemical and new SHRIMP age data, and discuss the origin of their peraluminous parent magmas.

\section{GEOLOGICAL SETTING}

The Strzelin Massif is located in the eastern part of the Fore-Sudetic Block, about $40 \mathrm{~km}$ south of Wrocław. The rocks of the massif crop out in the Lipowe Hills and in the Strzelin Hills between faults parallel to the valleys of two small rivers: the Mała Ślęża on the west and the Krynka on the east (Fig. 1B). The Strzelin Massif is composed of two tectonic units.

The lower unit comprises rocks of the Strzelin Complex, specifically, the Strzelin and Nowolesie gneisses (600-570 Ma, Oberc-Dziedzic et al., 2003; Klimas, 2008; Klimas et al., 2009; Mazur et al., 2010), the older schist series of mica schists, amphibolites, calc-silicate rocks and marbles of unknown age, and the younger schist series (probably Early Devonian in age, Oberc, 1966), represented by quartzites, quartz-sericite schists and metaconglomerates of the Jegłowa Beds. The rocks of the lower unit belong to Brunovistulicum (Oberc-Dziedzic and Madej, 2002; Oberc-Dziedzic et al., 2003, 2005, 2010).

The upper unit comprises rocks of the Stachów Complex: orthogneisses (c. 500 Ma, Oliver et al., 1993; Klimas, 2008; Mazur et al., 2010), paragneisses, biotite-amphibolite schists and amphibolites. The Stachów Complex was interpreted as a part of Moldanubicum, based on the presence of c. 500 Ma old orthogneisses that are also common in the Moldanubian Zone (Oberc-Dziedzic and Madej, 2002; Turniak et al., 2000). In the Strzelin Massif, the rocks of the Moldanubicum-related Stachów Complex were thrust over the Brunovistulicum-related Strzelin Complex along the Strzelin Thrust (Oberc-Dziedzic and Madej, 2002) which is regarded as the northern continuation of the Moldanubian Thrust (Suess, 1926) in the Fore-Sudetic
Block. The rocks of the Strzelin Complex are exposed mainly in the eastern part of the Strzelin Massif (the Strzelin Hills), whereas the rocks of the Stachów Complex crop out in its western part (the Lipowe Hills) and as klippes in the Strzelin Hills (Fig. 1B).

The metamorphic rocks of both Strzelin and Stachów complexes were intruded by Variscan granitoids represented by quartz diorite, tonalite, granodiorite, biotite granite and Bt-Ms granite. These granitoids were emplaced in three stages: (1) tonalitic I - at c. $325 \mathrm{Ma}$, (2) granodioritic - at c. $305 \mathrm{Ma}$ and (3) tonalitic II/granitic - at c. 295 Ma (Oberc-Dziedzic et al., 2010; Oberc-Dziedzic and Kryza, 2012). SHRIMP zircon age data $\left({ }^{206} \mathrm{~Pb} /{ }^{238} \mathrm{U}\right.$ ages) available for the biotite granites of the Strzelin intrusion (303 $\pm 2 \mathrm{Ma}$ for the medium-grained granite, and $283 \pm 8 \mathrm{Ma}$ for the fine-grained granite) indicate that they represent, respectively, the second and third magmatic stages (Oberc-Dziedzic et al., 2013). The Bt-Ms granites also belong to the third stage of magmatism in the Strzelin Massif.

The Bt-Ms granites form either (1) broadly isometric or irregular bodies, in this paper referred to as small plutons (the Gromnik, Gębczyce and Górka Sobocka intrusions), or (2) dykes cutting across metamorphic rocks, tonalites and biotite granites (Figs. 2 and 3). The Gromnik and Gębczyce bodies are situated along a fault that separates the Strzelin and Nowolesie gneisses in the Strzelin Hills. Based on field data and observations from two boreholes, the shape of the Gromnik Pluton was defined as stock-type, with a 150-200 m thick, flat apophysis (Fig. 3; Oberc-Dziedzic, 1991 and reference therein). The Gębczyce granite body is probably of similar shape. The exposed part of this intrusion corresponds to a stock, as suggested by a steep, nearly vertical contact of the granite with the country rocks and by a higher dip of the country rock foliation near the contact with the granite. The granites with dark nodules characteristic of the Gębczyce intrusion, which were drilled c. 2 and $3 \mathrm{~km}$ to the north of the exposed part of the intrusion, probably build apophyses, 18 and 28 m thick, respectively, branching
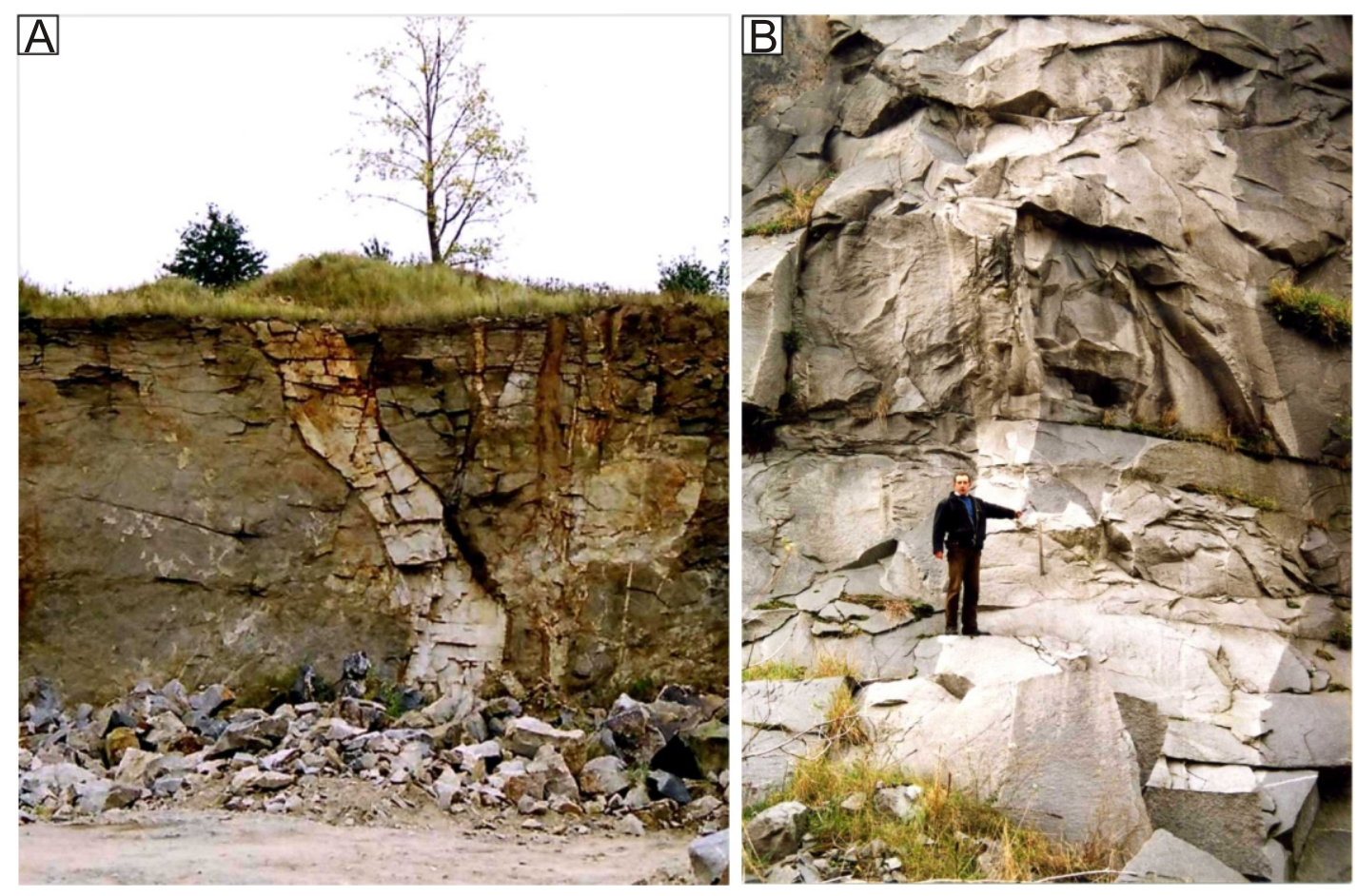

Fig. 2. Dykes of the biotite-muscovite granite cutting

A - tonalite in the Gęsiniec Quarry; B - fine-grained biotite granite in the Strzelin I Quarry 


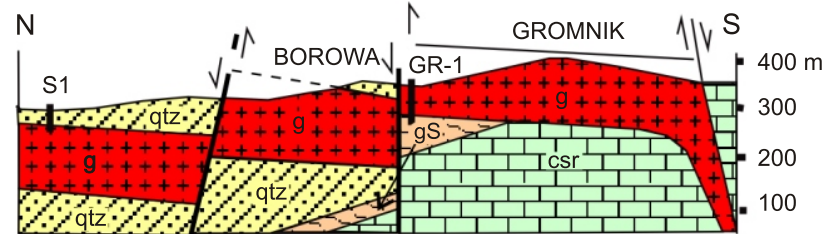

$100 \mathrm{~m}$.
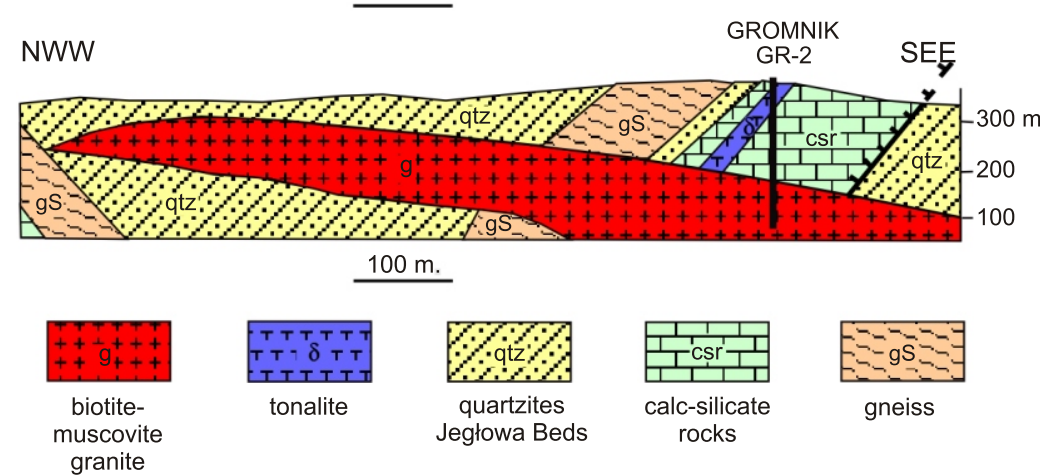

Fig. 3. Cross-sections through the Gromnik intrusion (Oberc-Dziedzic, 1991 and references therein)

off the main body. The shape of the Górka Sobocka Pluton is unknown.

The metamorphic envelopes of the Gromnik and Gebczyce intrusions are composed of the older schist series of the Strzelin Complex. The Górka Sobocka and the Strzelin intrusions (Fig. 1B), hosting dykes of the Bt-Ms granites (Oberc-Dziedzic et al., 2013), are enveloped by the Stachów Complex rocks. The Gęsiniec small pluton (Fig. 1B), composed of tonalite-diorite and comprising dykes of the Bt-Ms granite (Oberc and Kryza, 2012), is surrounded by the Strzelin gneisses.

\section{MATERIALS AND METHODS}

The samples selected for petrographic and geochemical investigations were collected in the Gębczyce, Strzelin I, Gęsiniec and Górka Sobocka quarries. Samples of the Gromnik granite were taken from blocks near the top of the hill. Fresh material valuable for investigations was obtained from boreholes drilled by the Przedsiębiorstwo Geologiczne (Geological Company), Wrocław, in the early 1980's: the Gromnik granite - GR-1 and GR-2 boreholes, and the Gębczyce granite - GW-1a, GW-1, D-1 and KL-2 boreholes.

The petrographic study of the Bt-Ms granites is based on 37 thin sections examined under the polarizing microscope. The chemical compositions of the rock-forming minerals, i.e. micas and feldspars, in six representative specimens of the Bt-Ms granites, have been determined with the CAMECA SX 100 instrument in the Electron Microprobe Laboratory Joint-Institute Analytical Complex for Minerals and Synthetic Substances, Faculty of Geology, the University of Warsaw. The analytical conditions were: acceleration voltage $15 \mathrm{kV}$, beam current $10 \mathrm{nA}$ for plagioclase and mica, and $20 \mathrm{nA}$ for the other minerals, and counting time 20 $\mathrm{s}$. The raw data were processed with the PAP software supplied by CAMECA. Mineral abbreviations used in this study are from Whitney and Evans (2010).
Five bulk-rock samples were analysed for major, trace and rare earth elements in the ACME Analytical Laboratories Ltd, Canada, and in the ALS Canada, using combined ICP-OES and ICP-MS techniques (see web site: acmelab.com). Three published analyses of the Bt-Ms granites from the Strzelin I Quarry (Oberc-Dziedzic et al., 2013) were also taken into consideration. Three samples of the Bt-Ms granites (GB 1 - Gębczyce, GOR - Górka Sobocka and $210-$ Gęsiniec) were analysed by one of the authors (CP) for Sm-Nd isotopes, following the procedure described by $P$ in and Santos Zalduegui (1997). The initial ${ }^{143} \mathrm{Nd} /{ }^{144} \mathrm{Nd}$ ratios are expressed as $\varepsilon \mathrm{Nd}_{\mathrm{i}}$ values, corrected for in situ decay of ${ }^{147} \mathrm{Sm}$, assuming an age of $295 \mathrm{Ma}$ for the granites, and model ages are calculated relative to the depleted mantle model of De Paolo (1981a, b). The new Sm-Nd isotope data of the Bt-Ms granites are compared with published data for the biotite and Bt-Ms granites from the Strzelin I Quarry (Oberc-Dziedzic et al., 2013) and unpublished data for the Gęsiniec tonalites. The $\varepsilon \mathrm{Nd}_{\mathrm{i}}$ values were corrected for in situ decay of ${ }^{147} \mathrm{Sm}$, assuming an age of $286 \mathrm{Ma}$ for the Bt-Ms granites and $295 \mathrm{Ma}$ for the tonalites.

Two samples of the Bt-Ms granite, one from Gębczyce and one from the Strzelin I Quarry, have been selected for SHRIMP zircon dating. Details of the SHRIMP analytical procedures are given in the geochronology section below. The published SHRIMP data for the Bt-Ms granite from Gęsiniec (Oberc-Dziedzic and Kryza, 2012) have also been taken into consideration in our discussion of the granite age.

\section{PETROGRAPHY}

The Bt-Ms granites, forming both small plutons and dykes, are white to yellowish or light grey, fine-grained rocks composed of quartz, plagioclase, K-feldspar, biotite and muscovite. The mineral components are randomly distributed; exceptionally, in the granites forming dykes in the Strzelin I Quarry, they define a planar fabric. The relative abundances of the major rock-forming minerals vary from intrusion to intrusion (Table 1), as do the shapes of minerals and their chemical compositions. The Bt-Ms granites of the dykes cutting the Gęsiniec tonalite

$\mathrm{T}$ a ble 1

Mineral composition of the Bt-Ms granites from the Strzelin Massif

\begin{tabular}{|l|c|c|c|c|c|}
\hline & Gromnik $^{1}$ & Gębczyce $^{1}$ & $\begin{array}{c}\text { Górka } \\
\text { Sobocka }\end{array}$ & Gęsiniec $^{3}$ & $\begin{array}{c}\text { Strzelin I } \\
\text { Quarry }\end{array}$ \\
\hline Quartz & 32.0 & 35.8 & 35.9 & 34.8 & 34.2 \\
\hline K-feldspar & 26.1 & 32.2 & 24.9 & 26.3 & 31.0 \\
\hline Plagioclase & 36.1 & 28.3 & 30.0 & 36.9 & 29.1 \\
\hline Biotite & 4.6 & 1.2 & 5.7 & 1.2 & 2.2 \\
\hline Muscovite & 1.0 & 0.8 & 3.1 & 0.8 & 2.7 \\
\hline Chlorite & - & 1.7 & 0.1 & - & - \\
\hline $\begin{array}{l}\text { Accessory } \\
\text { minerals }\end{array}$ & 0.2 & - & 0.3 & - & 0.8 \\
\hline
\end{tabular}

${ }^{1}$ Bereś (1969); ${ }^{2}$ Wojnar (1977), average of 9 analyses (Oberc-Dziedzic and Pin, 2000); ${ }^{3}$ Oberc-Dziedzic and Kryza (2012); ${ }^{4}$ Morawski and Kościówko (1975) 

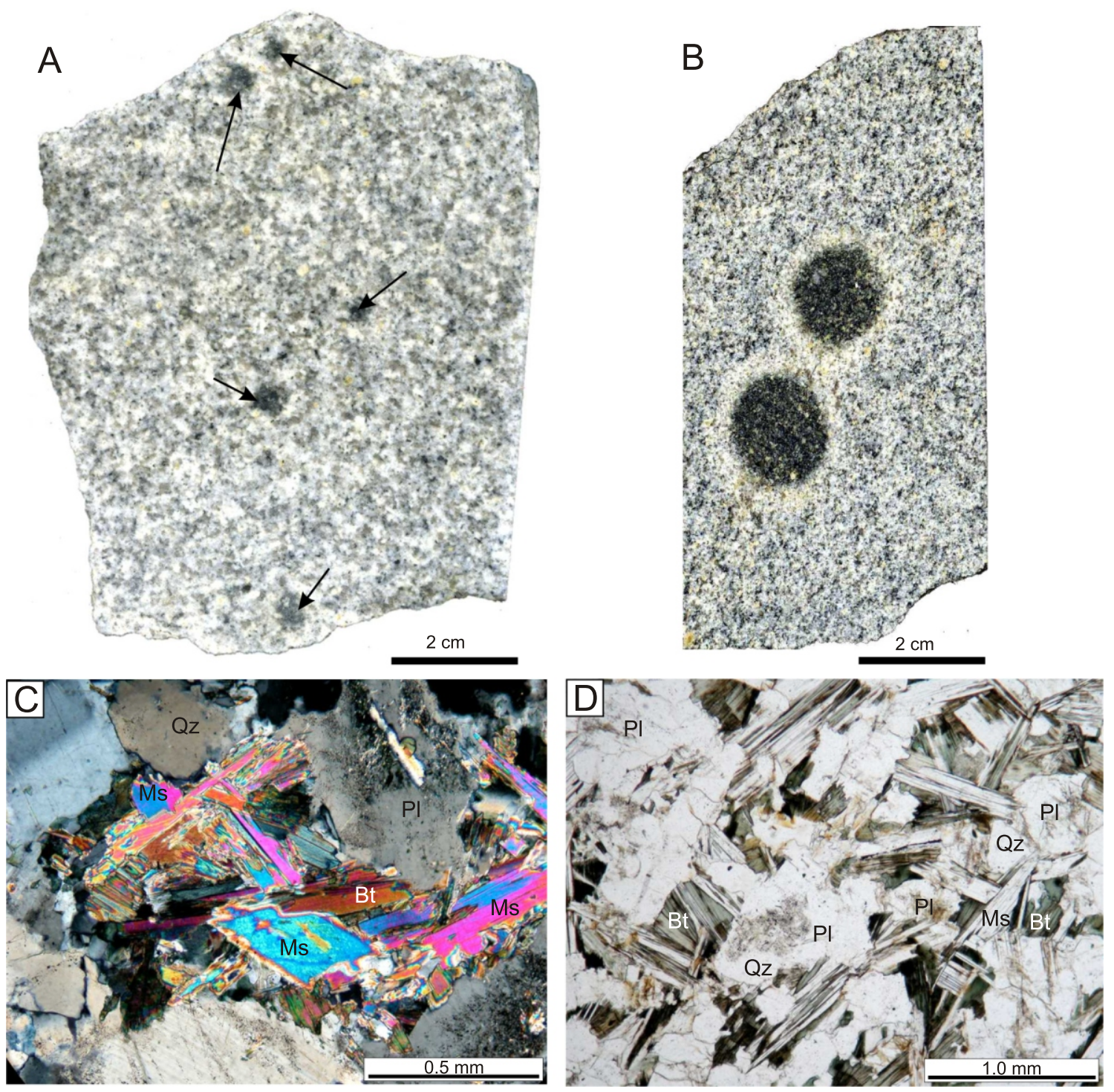

Fig. 4. Pinite in the biotite-muscovite granites

A - pinite clusters (arrows indicate location of clusters) in the granite from the dyke in the Gesiniec Quarry; B - the Gębczyce granite with dark nodules surrounded by white rims; C - pinite recrystallised into green biotite (Bt) and muscovite (Ms) with jagged margin associated by zoned plagioclase $(\mathrm{PI})$ and quartz $(\mathrm{Qz})$ grains, crossed polars; $\mathbf{D}$ - pinite from dark nodules in the Gębczyce granite recrystallised into green biotite (Bt) and muscovite (Ms); on the left, rectangular biotite pseudomorph after cordierite; biotite plates are arranged into triangular forms; plagioclase (PI) with cloudy interiors and rounded quartz $(\mathrm{Qz})$ grains are concealed between pinite; plane-polarized light; mineral abbreviations from Whitney and Evans (2010)

and the Strzelin granite contain sparse, $0.5-1 \mathrm{~cm}$ in size, pinite pseudomorphs after cordierite (Fig. 4A). A typical feature of the Gębczyce granite is the presence of dark, oval nodules, $1-3 \mathrm{~cm}$ across, surrounded by $2-5 \mathrm{~mm}$ wide, white-coloured rims (Fig. 4B).

K-feldspar (Appendix $1^{*}$ ). In all Bt-Ms granites, K-feldspar forms anhedral grains with cross-hatched patterns. Usually, it contains inclusions of rounded quartz grains, rare euhedral inclusions of plagioclase (in Gębczce) or tiny plates of biotite (in Gromnik). In the Górka Sobocka granite, numerous rounded quartz inclusions are present, both in microcline and in plagioclase enclosed in microcline, and they cross-cut the boundary between these feldspars (Fig. 5A).

In all Bt-Ms granites, the K-feldspar contains: Or 86-98 mol.\%, An $0-0.6 \%$, and Ab $2-14 \%$ of Ab. The celsian (Cls) component is usually between $0.1-1.2 \%$. Significantly higher Cls, $2.3-2.5 \%$, is found in internal parts of microcline grains in the Gromnik and Górka Sobocka granites.

Plagioclase (Appendix 2). Plagioclase differs in various Bt-Ms granites. In the Gromnik granite, plagioclase forms two types of grains. The first is represented by narrow tabular crystals, c. $1.0 \times 0.25 \mathrm{~mm}$ in size (Fig. $5 \mathrm{~B}$ ), or roughly isometric forms, $1.0-1.2 \mathrm{~mm}$ in diameter (Fig. $5 \mathrm{C}$ ). From the centre to the

* Supplementary data associated with this article can be found, in the online version, at doi: $10.7306 / \mathrm{gq} .1248$ 

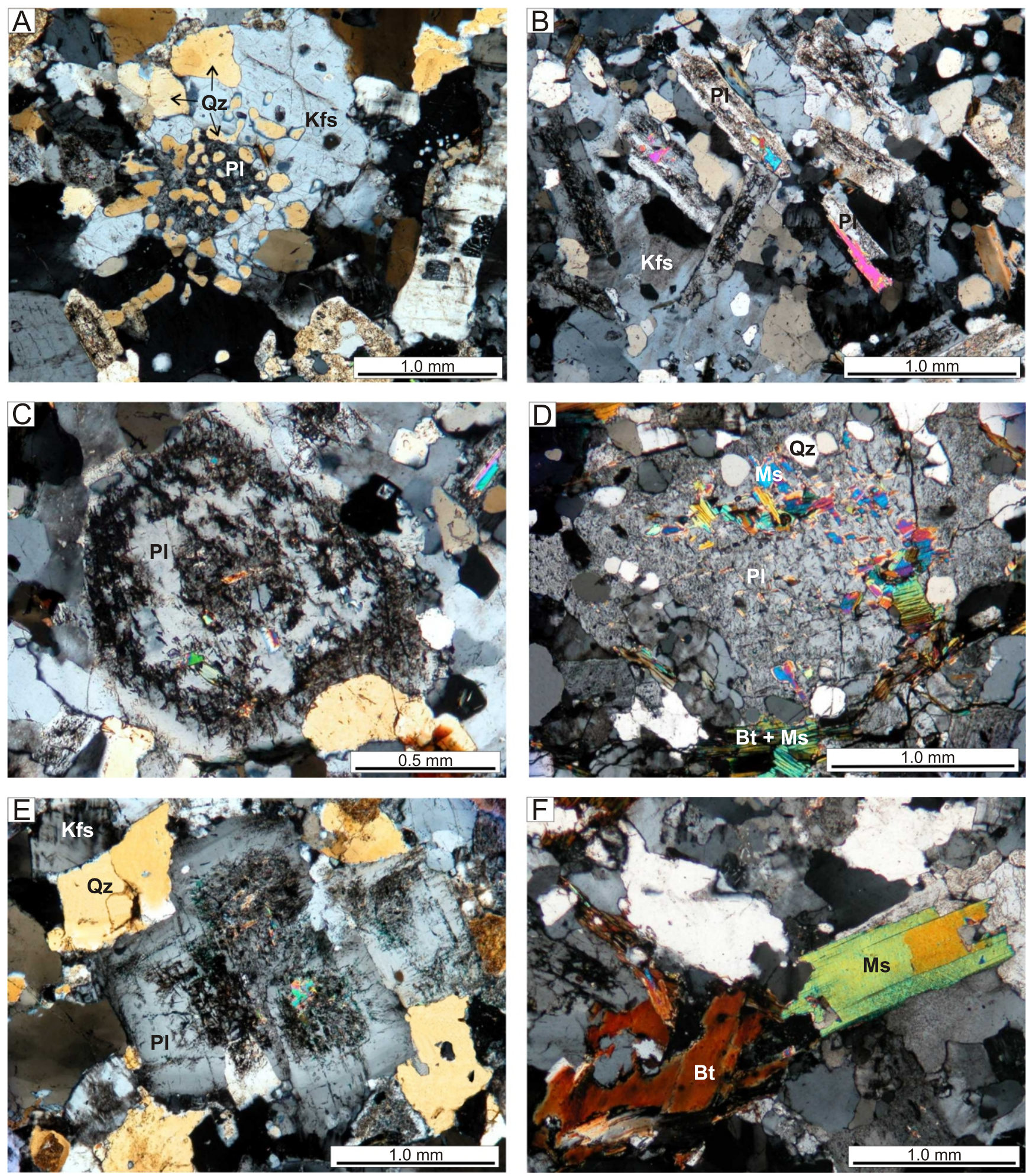

Fig. 5. Mineralogy and textures of the biotite-muscovite granites from the Strzelin Massif

A - K-feldspar (Kfs) in the Górka Sobocka granite with inclusion of plagioclase (PI); numerous rounded quartz (Qz) inclusions are present both in microcline and plagioclase; B - narrow tabular plagioclases (PI) containing muscovite inclusions and K-feldspar (Kfs) in the Gromnik granite; $\mathbf{C}$ - roughly isometric plagioclase $(\mathrm{PI})$ in the Gromnik granite showing etched external ring and etched center; $\mathbf{D}-$ rounded grain of plagioclase $(\mathrm{PI})$ in the Geebczyce granite; the grain contains inclusions of drop-like quartz $(\mathrm{Qz})$ forming a ring parallel to the grain border, and inclusions of muscovite (Ms) in singular plates and small concentrations; in the matrix, muscovite is arranged into stripes accompanied by biotite (Bt + Ms); $\mathbf{E}$ - cross-like cluster of plagioclase (glomerocrystals) surrounded by a common rim of plagioclase (PI), K-feldspar (Kfs) and quartz (Qz) in the Gęsiniec Bt-Ms granite; F - muscovite (Ms) and biotite (Bt) plates in the Górka Sobocka granite; crossed polars 
margin of the grains, they display an inner part with $16-19 \%$ An, followed by an etched ring containing $26-40 \% \mathrm{An}$, and, finally, a clear external zoned rim of $22-12 \%$ An. In some grains, the inner part has an etched center with $27 \%$ An. The plagioclase grains of the second type have rectangular outlines and the albite twinning, and show normal zoning of 24-14\% An (Fig. 5C).

In the Gębczyce granite, plagioclase is usually subhedral or anhedral. The subhedral crystals show an etched interior surrounded by a rather indistinct etched ring. Such crystals have up to $27.5 \%$ An in the internal part and $12-16 \%$ An in the rim. Small tabular plagioclase grains, with etched internal part, found as inclusions in K-feldspar, contain 13-15\% An. The second type of plagioclase in this granite is represented by "dusty" grains, $2 \mathrm{~mm}$ in diameter, with a ring rich in rounded quartz inclusions in the external part. These grains contain small clusters of muscovite and biotite inclusions. Anorthite content is in the range of $6-14 \%$ (Fig. 5D).

In the Górka Sobocka granite, plagioclase forms also two types of grains. The first subhedral variety is composed of a "dusty" internal part and surrounding clean rim. The chemical zonation in this type is poorly expressed. Larger grains (up to $1.5 \mathrm{~mm}$ ) have $13-16.5 \% \mathrm{An}$ in the center, $18-22 \%$ An in the intermediate zone, and $11-16 \%$ An in the rim. Such a zonal sequence is similar to that in the Gromnik granite, but the An content in each zone is lower. Smaller grains of type I have 19\% An in the center $14 \% \mathrm{An}$ in the rim. The second variety of plagioclase comprises small unzoned grains, containing only $3.5 \%$ An and anhedral grains having $9.5-12.3 \%$ An, with rounded quartz inclusions.

In the Gęsiniec granite, plagioclase forms euhedral to subhedral grains with etched/altered interiors or well-visible etched rings, similarly as in the Gromnik and Górka Sobocka granites. Occasionally, clusters of grains (glomerocrystals, $19-24 \% \mathrm{An})$ are surrounded by a common rim $(8.5 \% \mathrm{An}$; Fig. 5E).

In the Bt-Ms granite from the Strzelin I Quarry, plagioclase has euhedral tabular forms, with etched dusty cores (18-21\% $\mathrm{An})$ and wide clear rims, normally (16.5-4.5\% An) or oscillatory (7.5-4.5\% An) zoned.

Summing up, plagioclases in the studied Bt-Ms granites show similar features, such as the presence of etched internal rings with elevated An content, surrounded by clear interiors, with lower An contents in one type of plagioclase, and with the albite twinning and lack of zoning in the other type. However, plagioclase in granites from particular intrusions, in spite of some similarities, have different An contents (Fig. 6). The narrow, tabular forms of plagioclase from the Gromnik granite, typical rather of tonalite than of granite, and the glomerocrystals from the Gęsiniec granite, are fairly unusual features as for plagioclase in granite.

Biotite (Appendix 3 ) is relatively abundant in the Gromnik and Górka Sobocka granites (4.6 and 5.7\%, respectively), but rarer in the Gębczyce, Gęsiniec (1.2\%) and Bt-Ms Strzelin granite $(2.2 \%$; Table 1). It forms small plates (Gromnik, Gębczyce, Strzelin), clusters of or individual large plates (Górka Sobocka, Gęsiniec), or small inclusions in plagioclase (Gęsiniec). It shows brown or reddish-brown (Górka Sobocka), to yellow pleochroism. Inclusions of zircon and monazite are scarce. In all Bt-Ms granites, biotite is slightly chloritised. The chloritisation is accompanied by the formation of ilmenite along the cleavage.

All the biotites from the Bt-Ms granites are classified as annite, except for the Bt-Ms granites from the Strzelin I Quarry, where it is siderophyllite (Fig. 7A). In the Gromnik and Gęsiniec granites, the Mg-number of biotite is about 0.3 , slightly higher than in the Gębczyce, Górka Sobocka and Strzelin granites

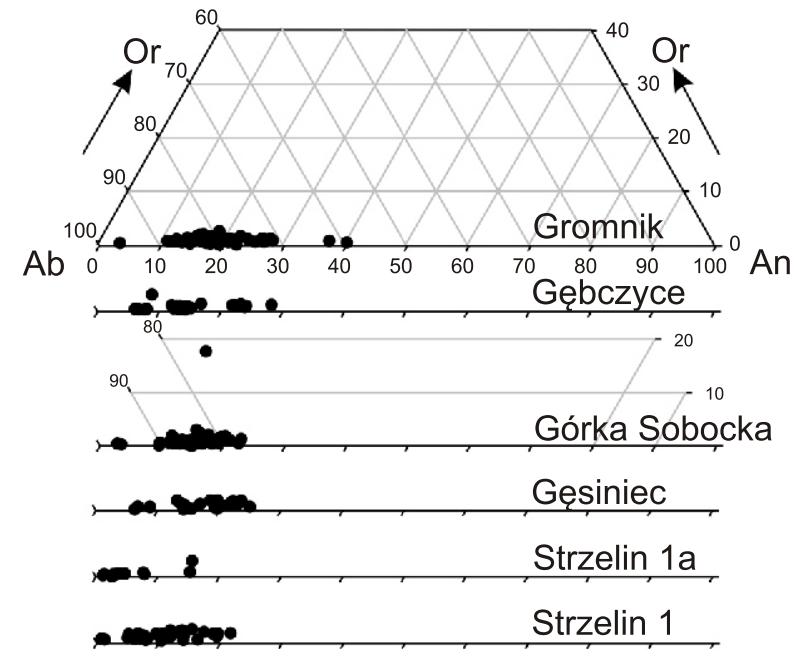

Fig. 6. Composition of plagioclase from biotite-muscovite granites of the Strzelin Massif

(0.24-0.2, 0.22-0.19, 0.24-0.14, respectively; Fig. 7A, B). Only a single, small, rounded biotite inclusion in plagioclase in the Gęsiniec granite has a higher Mg-number of 0.56. In almost all $\mathrm{Bt}-\mathrm{Ms}$ granites, the $\mathrm{Al}^{\mathrm{Vl}}$ content in biotite is $0.7-1.0$, only in the Strzelin granite, it is $>1.0$ (Fig. 7A). The $\mathrm{TiO}_{2}$ contents in biotite are between $2.3-4.8 \mathrm{wt} . \%$ and may change in different parts of the same biotite plate (Fig. 7B, C).

Muscovite (Appendix 4). In the Gromnik granite, muscovite forms inclusions in plagioclase (Fig. 5B), usually rectangular in shape or, exceptionally, elongated plates outside plagioclase. The chemical composition of muscovite is very constant (Fig. 8). The paragonite component is $<10 \mathrm{~mol} . \%$. Only one of 17 analyses revealed the presence of the margarite component ( 0.53 wt. $\%$ of $\mathrm{CaO}$ ). In various plates, the $\mathrm{TiO}_{2}$ concentration varies irregularly from $0.61-0.78 \mathrm{wt} . \%$ to $0.38-0.47 \mathrm{wt} . \%$, exceptionally to 0.22 wt.\% (Fig. 9).

In the Gębczyce granite, muscovite forms inclusions in plagioclase, small concentrations or singular plates in the matrix, and stripes of flakes (Fig. 5D). Some muscovite crystals are intergrown with biotite. The chemical composition of muscovite does not vary with the textural position in the rock and does not depend on grain size (Fig. 8). Paragonite contents are $8-4 \mathrm{~mol} . \%, \mathrm{TiO}_{2}$ 0.41-0.66 wt.\%, rarely less (0.02-0.32 wt.\%) (Fig. 9).

In the Górka Sobocka granite, muscovite forms three varieties: (a) large individual plates, (b) muscovite plates overgrown with biotite (Fig. 5F), and (c) small inclusions in plagioclase. All measured large plates and plates overgrown with biotite show very similar composition (Fig. 8) and similar contents of $\mathrm{TiO}_{2}$ (0.64-0.83 wt.\%; Fig. 9). The tiny muscovite inclusions in plagioclase have different composition, containing less $\mathrm{TiO}_{2}$ (0.01-0.32 wt.\%) and more $\mathrm{SiO}_{2}$ (about $6.3 \mathrm{apfu}$ ) than the large plates (6.1 apfu).

In the Gęsiniec granite, muscovite is rare. It forms very small flakes between quartz and plagioclase, and very small inclusions in plagioclase. The $\mathrm{TiO}_{2}$ content in the inclusions is very low: $0.02-0.15$ wt.\% (Fig. 9). The inclusions are probably products of plagioclase alteration. Only one muscovite plate, overgrown with biotite, has a higher $\mathrm{TiO}_{2}$ content of $0.6 \mathrm{wt} . \%$. The plates containing $0.02-0.03$ wt. $\% \mathrm{TiO}_{2}$ have over $38 \mathrm{wt} . \%$ $\mathrm{Al}_{2} \mathrm{O}_{3}$, whereas the other plates are lower in alumina (33-36 wt.\%). Most of the muscovites in this granite have about 6.2 apfu of Si. 
A

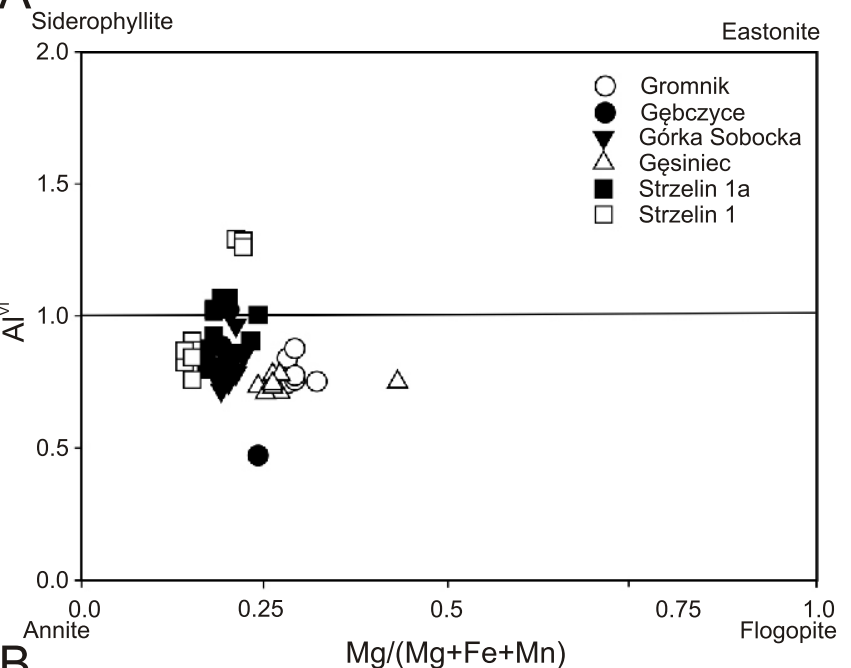

B

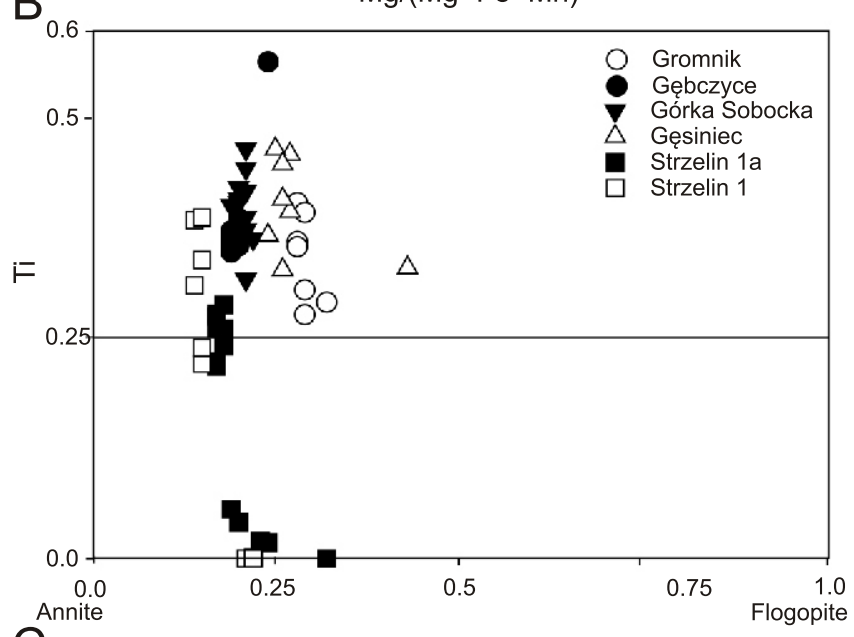

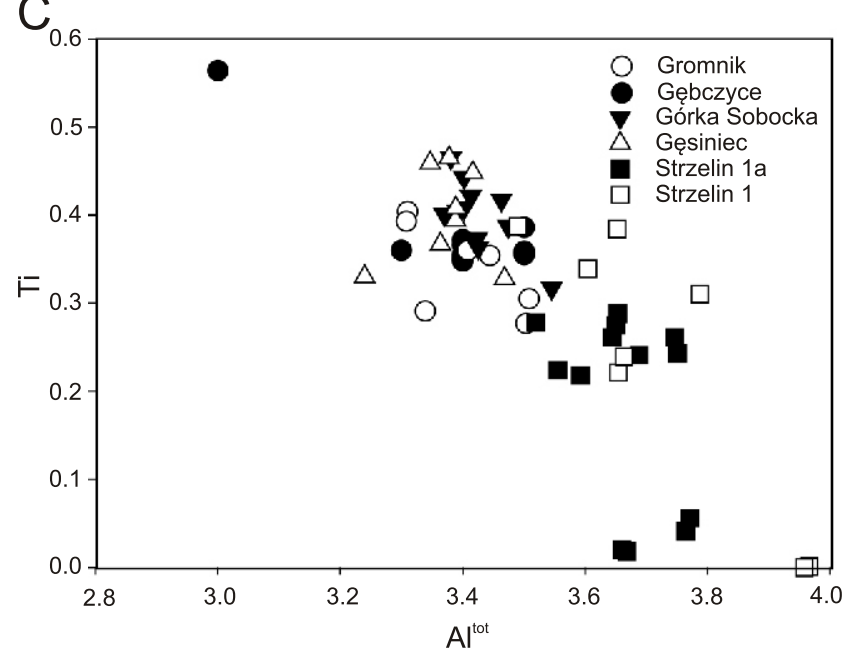

Fig. 7. Composition of biotite from biotite-muscovite granites of the Strzelin Massif plotted on diagrams

A $-\mathrm{Al}^{\mathrm{VI}}-\mathrm{Mg} /(\mathrm{Mg}+\mathrm{Fe}+\mathrm{Mn}) ; \mathbf{B}-\mathrm{Ti}^{4+}-\mathrm{Mg} /(\mathrm{Mg}+\mathrm{Fe}+\mathrm{Mn}) ; \mathbf{C}-\mathrm{Ti}^{4+}-\mathrm{Al}^{\text {tot }}$

In the Bt-Ms granite from the Strzelin I Quarry, muscovite forms: (a) plates overgrown with biotite, (b) inclusions in plagioclase, and (c) small flakes in pinite pseudomorphs after cordierite. The $\mathrm{TiO}_{2}$ content is, respectively: 0.23-0.47 wt.\%, 0.02 wt. \% and c. 0.01 wt.\% (Fig. 9). All three types of muscovite have about 6.05 apfu of $\mathrm{Si}$.

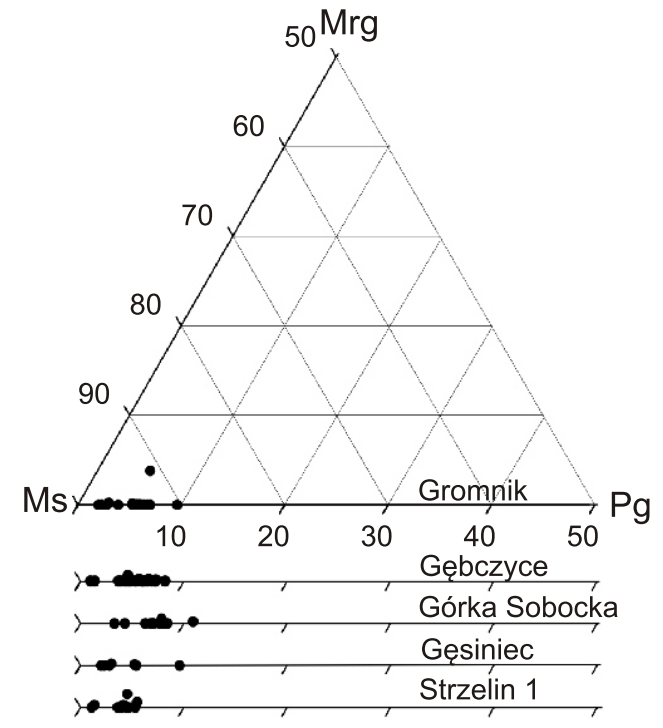

Fig. 8. Composition of muscovite from biotite-muscovite granites of the Strzelin Massif

On the discrimination diagram of Miller et al. (1981) (Fig. 10), the majority of the muscovite analyses fall into the primary muscovite (PM) field, i.e. all muscovites from the Gromnik granite (those forming both inclusions in plagioclase and plates in the matrix), most muscovites from the Gębczyce and Górka Sobocka granites, and some analyses of muscovite from the Gęsiniec and Strzelin granites. Analyses of the muscovite in small inclusions in plagioclase from the Gębczyce, Górka Sobocka and Gęsiniec granites, as well as those of the after-cordierite muscovites, fall into the secondary muscovite (SM) field. A few analyses of the muscovite inclusions in plagioclase from the Gęsiniec and Strzelin granites, and one analysis of the after-cordierite muscovite from the Strzelin granite plot outside the PM and SM fields, near the Na-corner of the diagram (Fig. 10).

Cordierite (pinite). The Bt-Ms granites from the dykes in the Strzelin I Quarry and in the tonalite quarry in Gęsiniec contain rare small clusters, about $0.5 \mathrm{~cm}$ in size, composed of green plates of biotite intergrown with muscovite (Fig. 4A), and of fan-like muscovite aggregates (Fig. 4C). Some clusters show rectangular forms (Oberc-Dziedzic et al., 2013). Occasionally, these clusters are surrounded by thin white rims. Although the clusters never contain fresh cordierite, they were interpreted as products of cordierite alteration, because of their similarity to recrystallised pinite pseudomorphs (Fig. 4C). It is worth mentioning that green biotite, characteristic for the clusters, does not occur in the granite matrix. The clusters are accompanied by subhedral, zoned plagioclase and rounded quartz grains.

A characteristic feature of the Gębczyce granite are dark nodules, a few $\mathrm{mm}$ to $3 \mathrm{~cm}$ across and sub-spherical in shape. They are mantled by 1-3 $\mathrm{mm}$ wide white rims (Fig. 4B). The nodules are composed of green biotite and muscovite, often intergrown, similar to those in the clusters described from dykes of the Bt-Ms granite. Biotite plates form either rare rectangular pseudomorphs after cordierite or, more often, they are arranged in triangles, enclosing rounded quartz (Fig. 4D). Such biotite triangles may be interpreted as pseudomorphs after cordierite twins, similar to those described by Vernon (2004). Apart from muscovite and green biotite, the nodules contain subhedral plagioclase with cloudy interiors, and rounded quartz grains. They do not contain K-feldspar. The white rims around the nodules show the same structure and mineral composition 


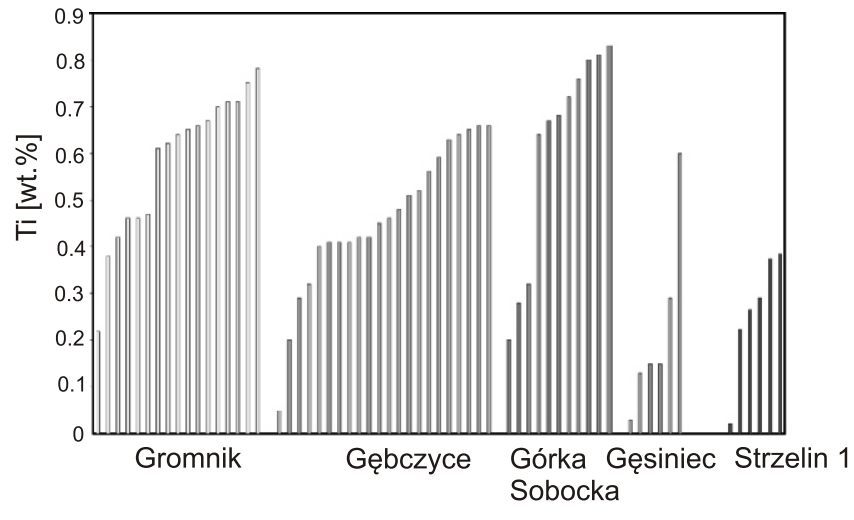

Fig. 9. $\mathrm{TiO}_{2}$ contents in muscovite from biotite-muscovite granites of the Strzelin Massif

as the host granite, but they do not contain biotite. In the external part of the nodule rims, Bereś (1969) found andalusite.

The difference between pinite clusters in the Bt-Ms granite dykes and the nodules in the Gębczyce granite is mainly quantitative: the clusters are small, the nodules several times larger. According to Clarke's (1995) classification, the cordierite belongs to Type 2c (Cotectic Magmatic), exceptionally to Type 2d (Fluido-Magmatic). It does not show features of Type 1a (Xenocrystic) and Type 1b (Restitic).

The nodules were interpreted as products of cordierite decomposition (Lorenc, 1987). Such a simple interpretation of the nodules does not explain their characteristic features, e.g. the perfect spherical shape, the presence of rounded quartz grains and of plagioclase of the same composition as the plagioclase in the matrix, the absence of K-feldspar, and the fact that the nodules do not represent a single pinitised grain of cordierite but contain many small grains of this mineral, enclosed between quartz and plagioclase. These features, besides the mineral composition, are similar as in microgranitoid enclaves described by Flood and Shaw (2014). Those enclaves were interpreted as crystal cumulates formed during pressure quench events caused by sudden loss of water from water saturated melts. In this model, the nodules could be crystal accumulations formed by heterogeneous nucleation of the quenched magma, probably around quartz phenocrysts, slightly resorbed at the onset of the quench event.

The white rims around the nodules might have formed due to the decomposition of biotite. $\mathrm{K}, \mathrm{Fe}$ and $\mathrm{Mg}$ from biotite migrated into the nodule, where they reacted with cordierite producing green biotite and muscovite. Andalusite could have been formed from $\mathrm{Al}_{2} \mathrm{O}_{3}$ and $\mathrm{SiO}_{2}$ left after the decomposition of

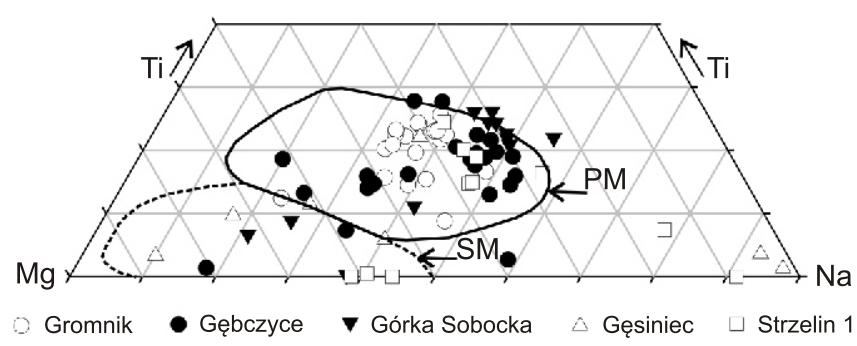

Fig. 10. Discrimination diagram of primary (PM) and secondary (SM) muscovites from biotite-muscovite granites of the Strzelin Massif (fields of muscovites after Miller et al., 1981) biotite. These reactions were probably stimulated by fluids circulating in the granite after the crystallisation of the magma.

\section{BULK-ROCK CHEMISTRY}

\section{MAJOR ELEMENTS}

In general, the fine-grained Bt-Ms granites, occurring as small plutons and dykes in the Strzelin Massif, show similar chemical composition. However, subtle but consequent differences in most major element concentrations are observed (Table 2). Specifically, the Bt-Ms granites of the small plutons contain, on average, $0.5-1$ wt. $\%$ less $\mathrm{SiO}_{2}, \mathrm{~K}_{2} \mathrm{O}$ and $\mathrm{Na}_{2} \mathrm{O}$ than the granites from the dykes, while they are two to three times richer in $\mathrm{Fe}_{2} \mathrm{O}_{3}, \mathrm{MgO}, \mathrm{CaO}$ and $\mathrm{TiO}_{2}$. Similar chemical differences are observed between the Górka Sobocka Bt-Ms granite and the Bt-Ms granites drilled across several metres thick dykes in the Lipowe Hills (Oberc-Dziedzic and Pin, 2000). According to the classification of Frost et al. (2001), the Bt-Ms granites of the small plutons and dykes are ferroan (Fig. 11A) and alkali-calcic (Fig. 11B). All granites are potassium-rich and peraluminous, with $\mathrm{A} / \mathrm{CNK}$ of 1.0-1.1 (Table 2) and with normative corundum (Wojnar, 1977; Oberc-Dziedzic and Pin, 2000).

\section{TRACE ELEMENTS}

The Bt-Ms granites of the small plutons are richer in $\mathrm{Ba}$ (588-685 ppm), Sr (78-117 ppm) and Zr (113-181 ppm) but contain less $U$ (2.7-7.4 ppm) than their dyke equivalents (Ba: 96-286, Sr: 21-63, Zr: 60-64, U: 3.2-14.5 ppm; Table 2). The multi-element diagram of trace element concentrations, normalized to chondrite, for the Bt-Ms granites of the plutons is characterized by strong $\mathrm{Nb}, \mathrm{Sr}, \mathrm{P}$ and $\mathrm{Ti}$ negative anomalies (Fig. 12A). Similar, but even deeper anomalies are visible on the multi-element diagram for the Bt-Ms granites of the dykes (Fig. 12C), which also displays a distinct, positive Ta anomaly. In the Bt-Ms granites of the small plutons, the total REE contents (195-230 ppm) are higher than in the Bt-Ms granites of the dykes (66-111 ppm; Table 2). The chondrite-normalized REE patterns for the plutons (Fig. 12B) display distinct, steeply decreasing LREE and HREE branches, and negative anomaly of Eu/Eu*, between $0.22-0.42$ (Table 2). The $(\mathrm{La} / \mathrm{Yb})_{\mathrm{N}}$ ratios range from 9 to 15. The chondrite-normalized REE patterns of the Bt-Ms granites of the dykes are characterized by distinct, steeply decreasing LREE and flat HREE patterns, and even deeper negative anomalies of Eu/Eu*, between 0.18-0.3 (Table 2). The $(\mathrm{La} / \mathrm{Yb})_{\mathrm{N}}$ ratios in these dyke granites are between 2.7 and 7.3, much lower than in the plutons. Both types of the Bt-Ms granites show a slight tetrad effect (Fig. 12B, D; Irber, 1999).

The trace-element diagram for the Bt-Ms granites of the small plutons, normalized to total crust (Fig. 13A), is generally similar to the diagram for the rocks of the dykes (Fig. 13C). However, the $\mathrm{Sr}$ and $\mathrm{Ti}$ negative anomalies and $\mathrm{Rb}$ and Ta positive anomalies are much more pronounced in the rocks of the dykes than those of the plutons, and the $\mathrm{P}$ anomaly, well-visible in granites of the plutons, is hardly noticeable in the dykes. The REE patterns normalized to total crust for the granites of the plutons broadly correspond to the average total crust composition but they display pronounced Eu anomalies (Fig. 13B). The REE patterns for the granites of the dykes are characterized by depletion in LREE, a strong Eu negative anomaly, and slight enrichment in HREE relative to LREE (Fig. 13D). 
Table 2

Chemical analyses of the Bt-Ms granites from the Strzelin Massif

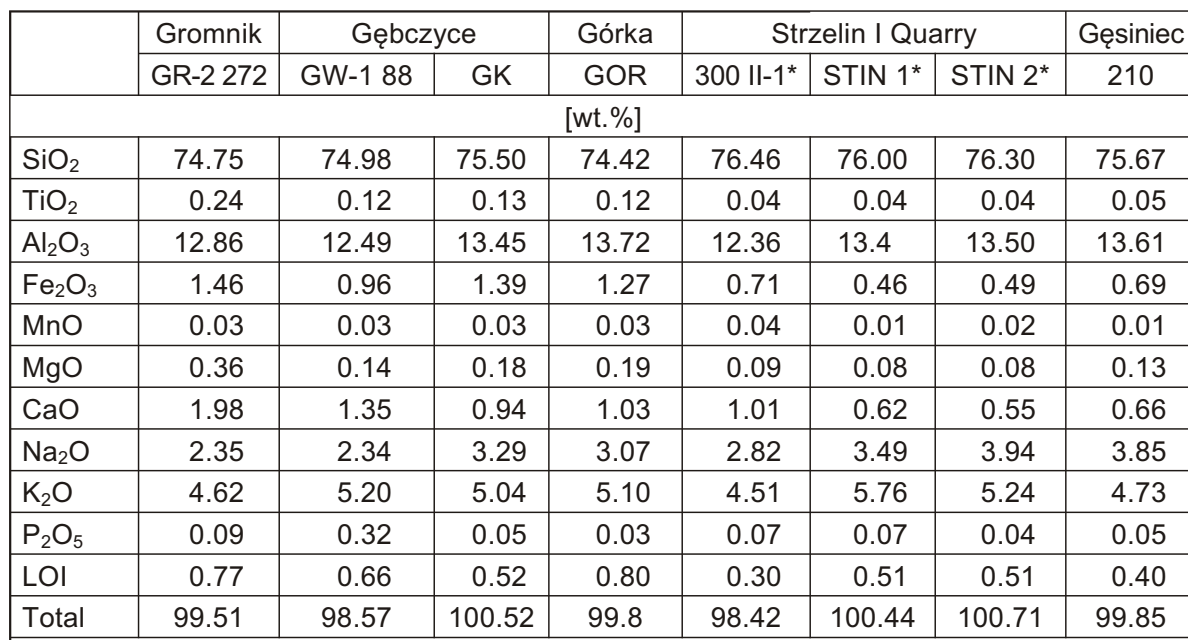

\begin{tabular}{|l|l|l|l|l|l|l|l|l|}
\hline A/CNK & 1.0 & 1.0 & 1.1 & 1.1 & 1.1 & 1.0 & 1.0 & 1.1 \\
\hline A/NK & 1.4 & 1.3 & 1.2 & 1.3 & 1.3 & 1.1 & 1.1 & 1.2 \\
\hline
\end{tabular}

\begin{tabular}{|l|l|l|l|c|c|c|c|c|}
\hline \multicolumn{10}{|c|}{$[\mathrm{ppm}]$} \\
\hline Co & 23 & 17 & 2 & 78 & 20 & 50 & 47 & 85 \\
\hline
\end{tabular}

\begin{tabular}{|l|c|c|c|c|c|c|c|c|}
\hline $\mathrm{V}$ & 11 & 5.3 & 9 & $<8$ & 6 & $<5$ & $<5$ & $<8$ \\
\hline $\mathrm{Pb}$ & 14 & 13 & 27 & 4 & 21 & 31 & 25 & 5.5 \\
\hline $\mathrm{Zn}$ & 36 & & 37 & 23 & 66 & 13 & 16 & 9 \\
\hline $\mathrm{Sn}$ & 5 & 3.6 & 7 & 6 & 4 & 3 & 4 & 2 \\
\hline $\mathrm{Rb}$ & 220 & 224 & 215 & 216 & 302 & 237 & 253 & 186 \\
\hline
\end{tabular}

\begin{tabular}{|c|c|c|c|c|c|c|c|c|}
\hline & & & & & & & & \\
\hline $\mathrm{Rb}$ & 220 & 224 & 215 & 216 & 302 & 237 & 253 & 186 \\
\hline $\mathrm{Cs}$ & 6.7 & 3.1 & 6.68 & 3.8 & 3.6 & 4.07 & 4.67 & 3.2 \\
\hline
\end{tabular}

\begin{tabular}{|l|l|l|l|l|l|l|l|l|}
\hline Cs & 6.7 & 3.1 & 6.68 & 3.8 & 3.6 & 4.07 & 4.67 & 3.2 \\
\hline $\mathrm{Ba}$ & 588 & 599 & 685 & 672 & 172 & 115 & 95.9 & 286 \\
\hline
\end{tabular}

\begin{tabular}{|c|c|c|c|c|c|c|c|c|}
\hline $\mathrm{Sr}$ & 117 & 78 & 95 & 80 & 35 & 29.2 & 21 & 63.3 \\
\hline $\mathrm{TI}$ & 1.1 & 1 & 0.9 & 0.2 & 1.4 & 0.8 & 0.9 & $<0.1$ \\
\hline $\mathrm{Ga}$ & 20 & 18 & 18.8 & 18 & 20 & 17.6 & 19.7 & 16.4 \\
\hline $\mathrm{Ta}$ & 7.9 & 6.4 & 1.6 & 1.6 & 7.5 & 3.4 & 8.8 & 2 \\
\hline
\end{tabular}

\begin{tabular}{|c|c|c|c|c|c|c|c|c|}
\hline $\mathrm{Ta}$ & 20 & 18 & 18.8 & 18 & 20 & 17.6 & 19.7 & 16.4 \\
\hline $\mathrm{Nb}$ & 20.5 & 6.4 & 1.6 & 1.6 & 7.5 & 3.4 & 8.8 & 2 \\
\hline $\mathrm{Hf}$ & 5.3 & 19.4 & 14.5 & 15 & 20.8 & 10.7 & 22.6 & 13.1 \\
\hline
\end{tabular}

\begin{tabular}{|l|c|c|c|c|c|c|c|c|}
\hline $\mathrm{Hf}$ & 5.3 & 3.8 & 3.9 & 4.1 & 2.6 & 2.4 & 2.6 & 2.6 \\
\hline $\mathrm{Zr}$ & 181 & 117 & 137 & 112.7 & 63 & 58 & 60 & 63.9 \\
\hline $\mathrm{Y}$ & & 36 & 30.7 & 32.6 & 26 & 25.5 & 23 & 25.2 \\
\hline
\end{tabular}

\begin{tabular}{|c|c|c|c|c|c|c|c|c|}
\hline $\mathrm{Zr}$ & 181 & 117 & 137 & 112.7 & 63 & 58 & 60 & 63.9 \\
\hline$Y$ & 26 & 38 & 30.7 & 32.6 & 26 & 25.5 & 23 & 25.2 \\
\hline Th & 21 & 20 & 19.95 & 21.3 & 13 & 10.55 & 10.9 & 13.6 \\
\hline U & 3.7 & 4 & 7.37 & 2.7 & 14.5 & 12.15 & 9.42 & 3.2 \\
\hline $\mathrm{La}$ & 55.6 & 53 & 42.7 & 42.4 & 20.4 & 12 & 12.6 & 22.8 \\
\hline $\mathrm{Ce}$ & 96 & 96.5 & 83.8 & 89.8 & 37.5 & 24 & 25.4 & 47.4 \\
\hline $\mathrm{Pr}$ & 10.3 & 10.2 & 8.96 & 10.23 & 3.9 & 2.66 & 2.75 & 5.52 \\
\hline $\mathrm{Nd}$ & 35.2 & 37 & 32.2 & 34.6 & 12.8 & 9.3 & 9.4 & 17.3 \\
\hline $\mathrm{Sm}$ & 6.5 & 7.6 & 6.37 & 6.81 & 3.3 & 2.68 & 2.73 & 3.82 \\
\hline $\mathrm{Eu}$ & 0.8 & 0.6 & 0.62 & 0.45 & 0.2 & 0.21 & 0.18 & 0.36 \\
\hline $\mathrm{Gd}$ & 5.4 & 6.9 & 6.27 & 5.67 & 3.4 & 3.11 & 2.99 & 3.52 \\
\hline $\mathrm{Tb}$ & 0.9 & 1.2 & 0.93 & 0.98 & 0.7 & 0.64 & 0.6 & 0.67 \\
\hline Dy & 4.8 & 7 & 5.55 & 5.29 & 4.4 & 4.24 & 4.08 & 3.9 \\
\hline $\mathrm{Ho}$ & 0.9 & 1.3 & 1.08 & 1.06 & 0.9 & 0.85 & 0.76 & 0.79 \\
\hline $\mathrm{Er}$ & 2.5 & 3.8 & 3.24 & 2.89 & 2.5 & 2.65 & 2.34 & 2.27 \\
\hline $\mathrm{Tm}$ & 0.4 & 0.6 & 0.45 & 0.48 & 0.4 & 0.4 & 0.38 & 0.37 \\
\hline $\mathrm{Yb}$ & 2.5 & 3.8 & 2.96 & 3.01 & 2.8 & 2.95 & 2.58 & 2.1 \\
\hline $\mathrm{Lu}$ & 0.4 & 0.6 & 0.43 & 0.44 & 0.4 & 0.42 & 0.39 & 0.32 \\
\hline S REE & 222.2 & 230.1 & 195.56 & 204.11 & 93.6 & 66.11 & 67.18 & 111.14 \\
\hline $\mathrm{La}_{\mathrm{N}} / \mathrm{Yb}_{\mathrm{N}}$ & 14.87 & 9.33 & 9.65 & 9.42 & 4.87 & 2.72 & 3.27 & 7.26 \\
\hline $\mathrm{Eu} / \mathrm{Eu}^{*}$ & 0.42 & 0.25 & 0.3 & 0.22 & 0.18 & 0.22 & 0.19 & 0.3 \\
\hline
\end{tabular}

A/CNK: $\mathrm{A}=\mathrm{mol} \mathrm{Al}_{2} \mathrm{O}_{3}, \mathrm{C}=\mathrm{mol} \mathrm{CaO}, \mathrm{N}=\mathrm{mol} \mathrm{Na}{ }_{2} \mathrm{O}, \mathrm{K}=\mathrm{mol} \mathrm{K}_{2} \mathrm{O} ; \mathrm{CNK}=\mathrm{C}+\mathrm{N}+\mathrm{K} ; \mathrm{NK}=\mathrm{N}+\mathrm{K}$;

*Oberc-Dziedzic et al. (2013) 
A
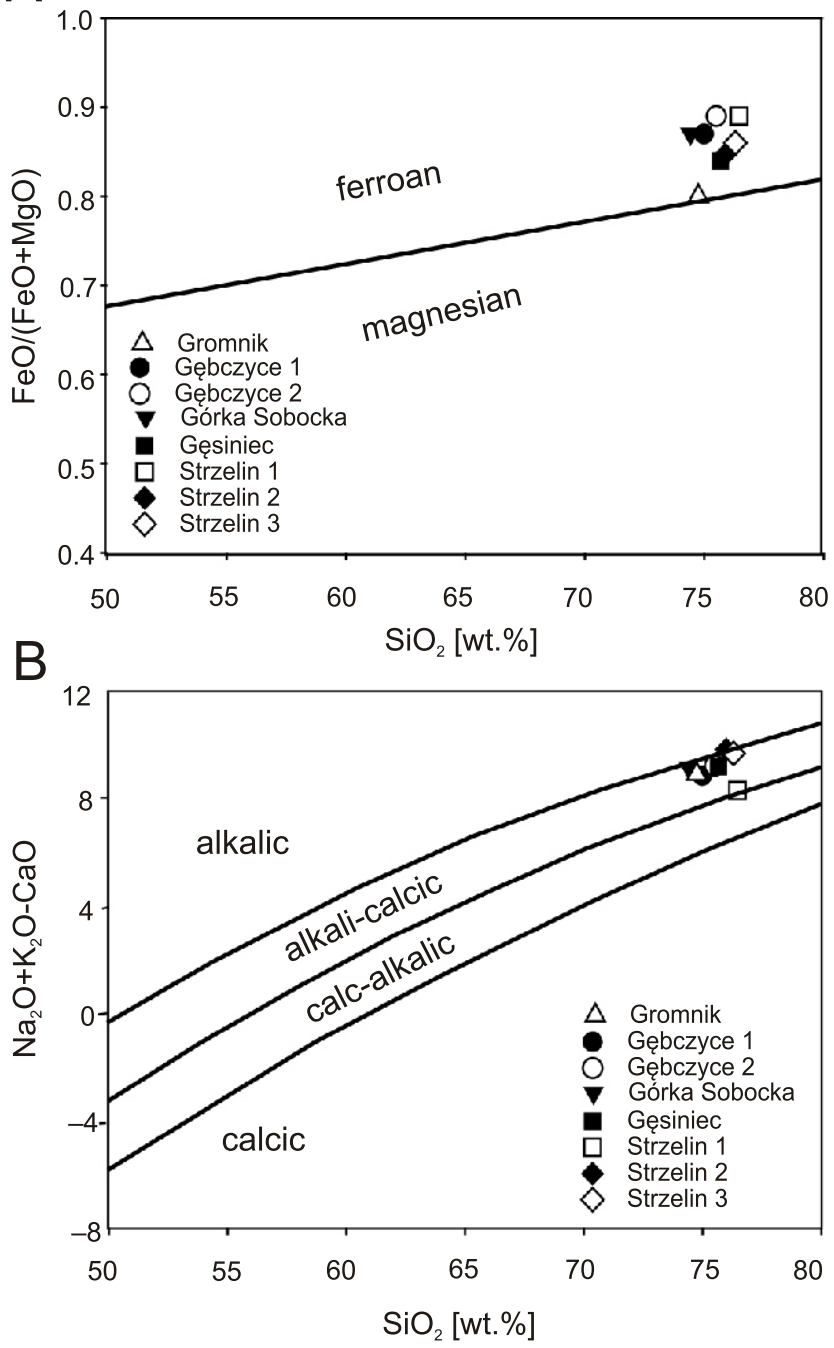

Fig. 11. Classification diagrams (Frost et al., 2001) for biotite-muscovite granites of the Strzelin Massif

A $-\mathrm{FeO} /(\mathrm{FeO}+\mathrm{MgO})$ vs. $\mathrm{SiO}_{2} ; \mathbf{B}-\mathrm{Na}_{2} \mathrm{O}+\mathrm{K}_{2} \mathrm{O}-\mathrm{CaO}$ vs. $\mathrm{SiO}_{2}$

Rb-Sr ISOTOPES

The $\mathrm{Sr}$ isotope data of the Bt-Ms granites from Oberc-Dziedzic et al. (1996) and Oberc-Dziedzic and Pin (2000) were corrected for in situ decay of ${ }^{87} \mathrm{Rb}$ by using the new age data (Oberc-Dziedzic et al., 2013). The age-corrected Sr isotope signatures for the Bt-Ms granites range as follows: ${ }^{87} \mathrm{Sr}^{86} \mathrm{Sr}_{\mathrm{i}}=295 \mathrm{Ma}$ from 0.7088 and 0.7086 for samples GB1 and GB 2 (Gębczyce granite, Table 3), to 0.7104 for sample GOR (Górka Sobocka granite), and ${ }^{87} \mathrm{Sr}^{86} \mathrm{Sr}_{\mathrm{i}}=286 \mathrm{Ma}$ up to 0.7191 , and even a higher value of 0.7260 for dyke samples STIN 1 and STIN 2 (Bt-Ms granite, Strzelin I Quarry), respectively.

\section{Sm-Nd ISOTOPES}

The Bt-Ms granites from the Gebczyce and Górka Sobocka plutons display ${ }^{147} \mathrm{Sm} /{ }^{144} \mathrm{Nd}$ ratios of 0.1144 and 0.1183 , intermediate between the value of 0.1067 measured in the fine-grained biotite granite from the Strzelin I Quarry
(Oberc-Dziedzic et al., 2013) and that of 0.1256 measured in the Bt-Ms granite dyke cutting the Gęsiniec tonalite (Table 4). The anomalously high ${ }^{147} \mathrm{Sm} /{ }^{144} \mathrm{Nd}$ ratios measured in the Bt-Ms granite dykes from the Strzelin I Quarry (0.1715-0.1804) were interpreted to reflect the fractionation of one or several LREE-rich accessory phase(s), e.g., monazite and/or apatite, as suggested by the low bulk-rock contents of $\mathrm{P}_{2} \mathrm{O}_{5}$ (Oberc-Dziedzic et al., 2013).

The Bt-Ms granites from the Gębczyce and Górka Sobocka quarries show $\varepsilon \mathrm{Nd}_{295}$ values of -4.5 and -4.9 , respectively, while the two samples of Bt-Ms granite dykes from the Strzelin I Quarry have an even less radiogenic $\mathrm{Nd}$ isotope signature $\left(\varepsilon \mathrm{Nd}_{286}-5.4\right.$ and -5.7$)$, as does the Bt-Ms granite from the dyke in the Gęsiniec Quarry $\left(\varepsilon_{\mathrm{Nd}_{295}}-5.9\right.$; Table 4$)$. All these data document geochemically evolved crustal sources for the parental magmas, dominated by an ancient LREE-enriched component, and point to a higher contribution of such a component in the late-stage, peraluminous dykes. The ${ }_{\varepsilon} \mathrm{Nd}_{300}$ of the fine-grained biotite granite $(-3.8)$ and the $\varepsilon \mathrm{Nd}_{295}$ of the diorite from the Gęsiniec Quarry (-4.0, -2.8; Table 4) are higher compared with those from the Bt-Ms granites, reflecting sources that were somewhat less enriched in LREE on a time-integrated basis, possibly as a result of subordinate contribution of mafic (mantle-derived?) material.

\section{ZIRCON SATURATION THERMOMETRY}

The Bt-Ms granites in small plutons (Gromnik, Gębczyce and Górka Sobocka granites) and of the dykes differ in their Zr concentrations: 113-181 ppm and 58-64 ppm, respectively (Table 2). To estimate the temperature of crystallisation of both types of Bt-Ms granites, we have applied the zircon saturation thermometry (Watson and Harrison, 1983; Miller et al., 2003). The samples of the Gębczyce and Górka Sobocka Bt-Ms granites yield nearly the same zircon-crystallisation temperatures, $\mathrm{T}_{\mathrm{zr}}$ of $765-779^{\circ} \mathrm{C}$ and $765^{\circ} \mathrm{C}$, respectively, whereas the Gromnik Bt-Ms granite shows a significantly higher $\mathrm{T}_{\mathrm{zr}}$ of $801^{\circ} \mathrm{C}$. The calculated $\mathrm{T}_{\mathrm{Zr}}$ of the Bt-Ms granites from the dykes cutting the biotite granites in the Strzelin I Quarry and the tonalites in the Gęsiniec Quarry, are very similar (706- $-720^{\circ} \mathrm{C}$ and $718^{\circ} \mathrm{C}$, respectively) and distinctly lower (by c. $40-80^{\circ} \mathrm{C}$ ) than the $\mathrm{T}_{\mathrm{zr}}$ of the Bt-Ms granites of the small plutons (Appendix 5 and Fig. 14A). For comparison, we have also calculated the $T_{z r}$ for the Strzelin biotite granites (Oberc-Dziedzic et al., $2013 ; 792-830^{\circ} \mathrm{C}$ ) and for the Gęsiniec tonalite-diorite: the dated sample of tonalite from Gęsiniec GT9, (Oberc-Dziedzic and Kryza, 2012) $-756^{\circ} \mathrm{C}$, and two samples of diorite (unpublished data) $747^{\circ} \mathrm{C}$ and $867^{\circ} \mathrm{C}$. The last temperature value is contained within the range of $\mathrm{T}_{\mathrm{zr}} 864-907^{\circ} \mathrm{C}$, calculated for the Gęsiniec granodiorite, based on the analyses published by Pietranik and Koepke (2009). Summing up, the $\mathrm{T}_{\mathrm{zr}}$ of the Bt-Ms granite in the dykes is about $100^{\circ} \mathrm{C}$ lower than in the host $\mathrm{Bt}$ granite, and $30-150^{\circ} \mathrm{C}$ lower than in the host tonalite and diorite, respectively (Appendix 5 and Fig. 14B).

\section{SHRIMP ZIRCON STUDY}

\section{SAMPLING AND METHODS}

Two samples of the biotite-muscovite granites, one (GEB) from the Gębczyce Quarry and one (300 III) from the dyke in the Strzelin I Quarry, have been selected for SHRIMP zircon investigations. The samples represent typical granites described in section Petrography. 
A

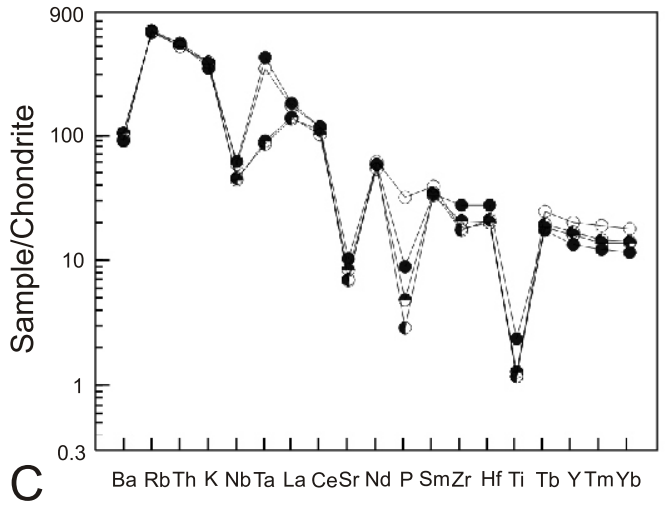

C

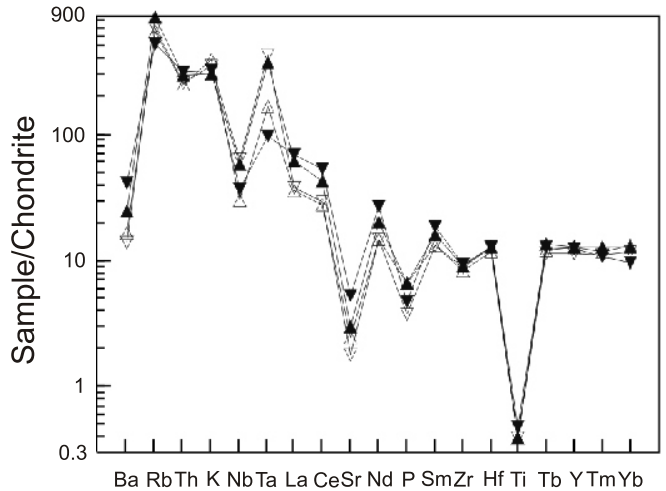

B
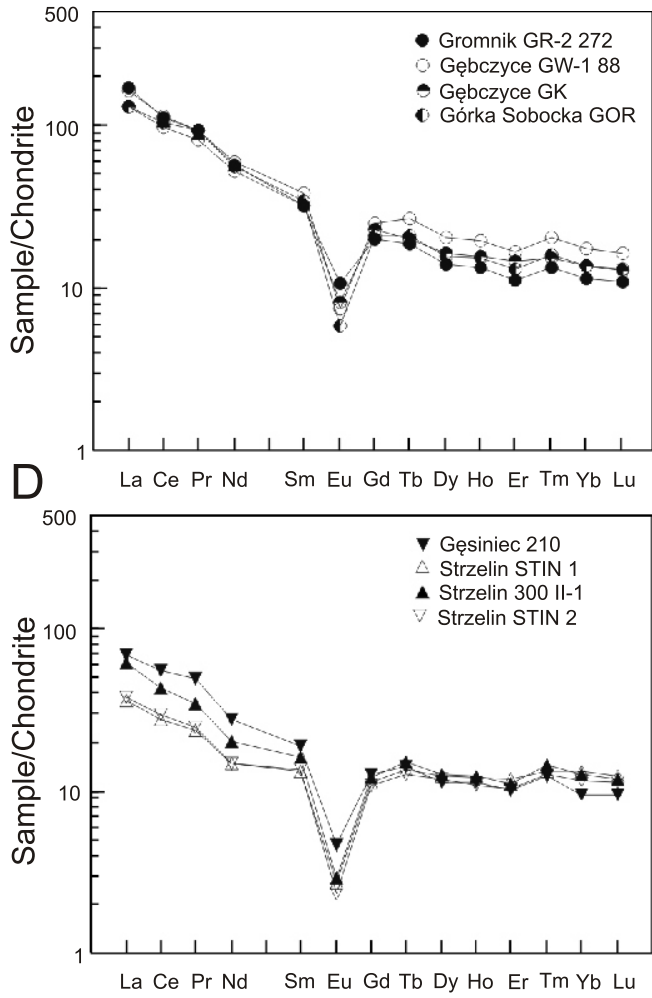

Fig. 12. Chondrite normalized

A, C - multi-element diagrams (normalization values of Thompson, 1982); B, D - REE plots (normalization values of Nakamura, 1974, with additions from Haskin et al., 1968) for biotite-muscovite granites from the Strzelin Massif: A, B diagrams for small plutons, C, D diagrams for dykes

A

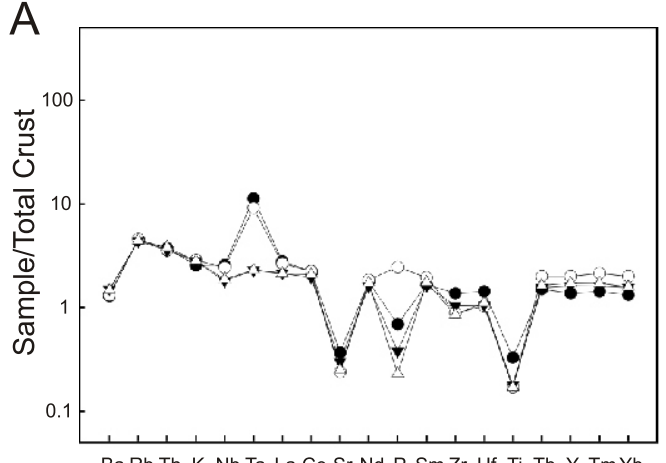

C

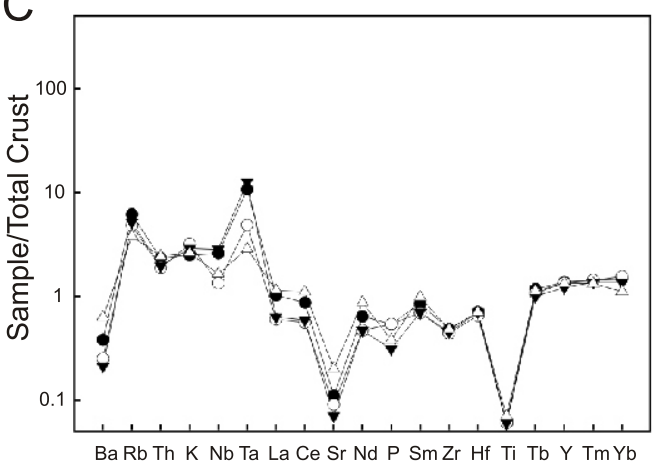

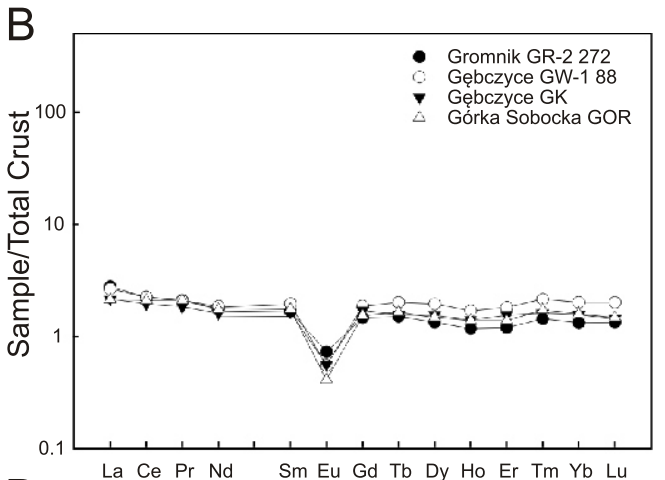

D

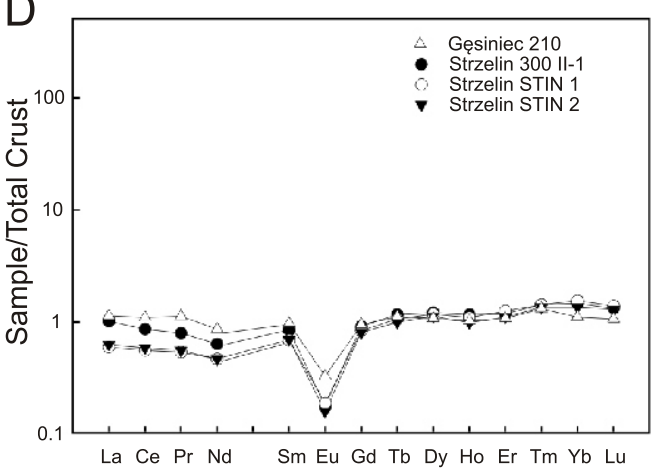

Fig. 13. Total-crust normalized (normalization values of Rudnick and Gao, 2005)

A, C - multi-element diagrams; B, D - REE plots for biotite-muscovite granites from the Strzelin Massif; A, B - diagrams were constructed for small plutons; C, D - diagrams for dykes 
$\mathrm{Rb}-\mathrm{Sr}$ results for the Bt-Ms granites of the Strzelin Massif

\begin{tabular}{|l|c|c|c|c|c|c|c|}
\hline & Type & $\mathrm{Rb}$ & $\mathrm{Sr}$ & ${ }^{87} \mathrm{Rb} /{ }^{86} \mathrm{Sr}$ & ${ }^{87} \mathrm{Sr} /{ }^{86} \mathrm{Sr}$ & ${ }^{87} \mathrm{Sr}^{86} \mathrm{Sr}_{(\mathrm{t})}$ & $(\mathrm{t})$ \\
\hline GB 1 & Gębczyce $^{*}$ & 220 & 90.1 & 7.09 & 0.73857 & 0.7088 & $(\mathrm{t}=295 \mathrm{Ma})$ \\
\hline GB 2 & Gębczyce $^{*}$ & 212 & 85.2 & 7.24 & 0.73901 & 0.7086 & $(\mathrm{t}=295 \mathrm{Ma})$ \\
\hline GOR & Górka Sobocka** $^{*}$ & 219 & 78.0 & 8.15 & 0.74457 & 0,7104 & $(\mathrm{t}=295 \mathrm{Ma})$ \\
\hline STIN 1 & Strzelin Quarry* & 239 & 30.6 & 22.80 & 0.81191 & 0.7191 & $(\mathrm{t}=286 \mathrm{Ma})$ \\
\hline STIN 2 & Strzelin Quarry & 255 & 20.3 & 32.60 & 0.85863 & 0.7260 & $(\mathrm{t}=286 \mathrm{Ma})$ \\
\hline
\end{tabular}

*Oberc-Dziedzic et al. (1996); **Oberc-Dziedzic and Pin (2000)

Sm-Nd isotope data for the Bt-Ms granites, biotite granite and tonalite of the Strzelin Massif

\begin{tabular}{|l|c|c|c|c|c|c|c|c|c|c|}
\hline Sample & Type & $\mathrm{Sm}$ & $\mathrm{Nd}$ & ${ }^{147} \mathrm{Sm} /{ }^{144} \mathrm{Nd}$ & ${ }^{143} \mathrm{Nd} /{ }^{144} \mathrm{Nd}$ & $\varepsilon \mathrm{Nd}_{0}$ & $\varepsilon N d_{(\mathrm{t})}$ & $\mathrm{t}[\mathrm{Ma}]$ & $\mathrm{T}_{\mathrm{CHUR}}$ & $\mathrm{T}_{\mathrm{DM}}[\mathrm{Ga}]$ \\
\hline GB 1 & Bt-Ms granite Gębczyce & 6.23 & 33.0 & 0.1144 & $0.512250(8)$ & -7.6 & -4.5 & 295 & 0.72 & 1.22 \\
\hline GOR & Bt-Ms granite Górka Sobocka & 7.02 & 35.8 & 0.1183 & $0.512240(3)$ & -7.8 & -4.9 & 295 & 0.78 & 1.29 \\
\hline 210 & Bt-Ms granite Gęsiniec & 4.05 & 19.5 & 0.1256 & $0.512200(2)$ & -8.6 & -5.9 & 295 & 0.94 & 1.46 \\
\hline STIN 1 & Bt-Ms granite Strzelin Quarry & 2.64 & 8.84 & 0.1804 & $0.512334(6)$ & -6.0 & -5.4 & 286 & $(2.86)^{* *}$ & $(3.44)^{* *}$ \\
\hline STIN 2 & Bt-Ms granite Strzelin Quarry & 2.79 & 9.84 & 0.1715 & $0.512299(7)$ & -6.6 & -5.7 & 286 & $(2.06)^{* *}$ & $(2.75)^{* *}$ \\
\hline STIN 3 & Bt granite Strzelin Quarry & 4.25 & 24.0 & 0.1067 & $0.512270(9)$ & -7.2 & -3.8 & 300 & 0.63 & 1.11 \\
\hline 4GT & tonalite Gęsiniec & 5.68 & 33.4 & 0.1028 & $0.512252(8)$ & -7.6 & -4.0 & 295 & 0.63 & 1.09 \\
\hline 5GT & tonalite Gęsiniec & 6.38 & 31.8 & 0.1213 & $0.512349(10)$ & -5.7 & -2.8 & 295 & 0.59 & 1.15 \\
\hline
\end{tabular}

*Oberc-Dziedzic et al. (2013); ** age spurious because of late-stage fractionation of Sm/Nd ratio
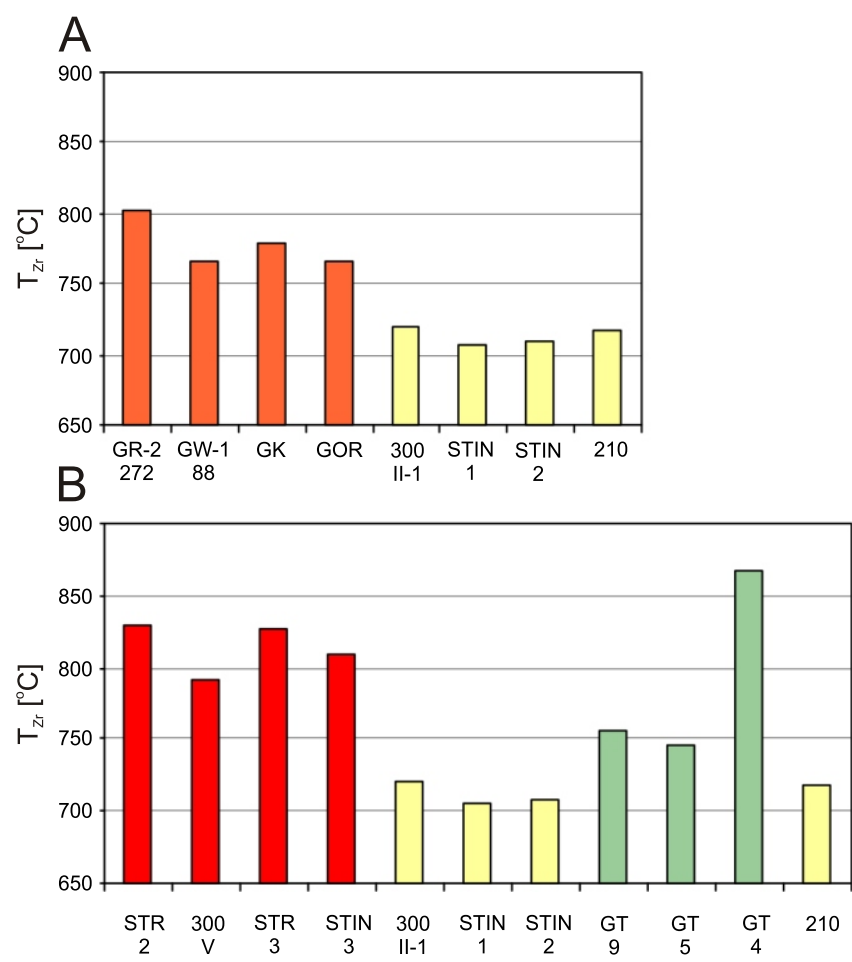

Fig. 14. Zircon saturation temperatures

A - for the biotite-muscovite granites from the Strzelin Massif (orange - plutons, yellow - dykes); B - for the Strzelin biotite granites (red) and the Gęsiniec tonalite-diorites (green) compared with biotite-muscovite granites of the dykes (yellow)
The samples selected for SHRIMP analysis, each c. $3-5 \mathrm{~kg}$ in weight, were crushed and the heavy mineral fraction $(0.06-0.25 \mathrm{~mm})$ was separated using a standard procedure with heavy liquids and magnetic separation. Zircons were hand-picked under a microscope, mounted in epoxy and polished. Transmitted and reflected light photomicrographs were made, along with $\mathrm{CL}$ images, in order to select grains and choose sites for analysis. The Sensitive High Resolution lon Microprobe (SHRIMP II) was used in the Beijing SHRIMP Center, Chinese Academy of Geological Sciences.

The U-Pb analyses were performed using a secondary electron multiplier in peak-jumping mode, following the procedure described in Williams (1998) or Larionov et al. (2004). A primary beam of molecular oxygen was employed to bombard zircon in order to sputter secondary ions. The elliptical analytical spots had a size of c. $25 \times 30 \mu \mathrm{m}$, and the corresponding ion current was c. $4 \mathrm{nA}$. The sputtered secondary ions were extracted at $10 \mathrm{kV}$. The $80 \mu \mathrm{m}$ wide slit of the secondary ion source, in combination with a $100 \mu \mathrm{m}$ multiplier slit, allowed mass-resolution of $\mathrm{M} / \Delta \mathrm{M} \geq 5000$ (1\% valley) so that all the possible isobaric interferences were resolved. Two-minute rastering was employed before each analysis in order to remove the gold coating and any possible surface common $\mathrm{Pb}$ contamination.

The following ion species were measured in sequence: ${ }^{196}\left(\mathrm{Zr}_{2} \mathrm{O}\right)-{ }^{204} \mathrm{~Pb}-$ background (c. $\left.204 \quad \mathrm{AMU}\right)-^{206} \mathrm{~Pb}-{ }^{207} \mathrm{~Pb}-$ ${ }^{208} \mathrm{~Pb}-{ }^{238} \mathrm{U}{ }^{248} \mathrm{ThO}-{ }^{254} \mathrm{UO}$ with integration time ranging from 2 to 20 seconds. Four cycles for each spot analysed were acquired. Each fifth measurement was carried out on the zircon $\mathrm{Pb} / \mathrm{U}$ standard TEMORA 1 (Black et al., 2003) with an accepted ${ }^{206} \mathrm{~Pb} /{ }^{238} \mathrm{U}$ age of $416.75 \pm 0.24 \mathrm{Ma}$. The 91500 zircon with a $U$ concentration of $81.2 \mathrm{ppm}$ and $\mathrm{a}{ }^{206} \mathrm{~Pb} /{ }^{238} \mathrm{U}$ age of 1062.4 $\pm 0.4 \mathrm{Ma}$ (Wiedenbeck et al., 1995) was applied as a "U-concentration" standard. 

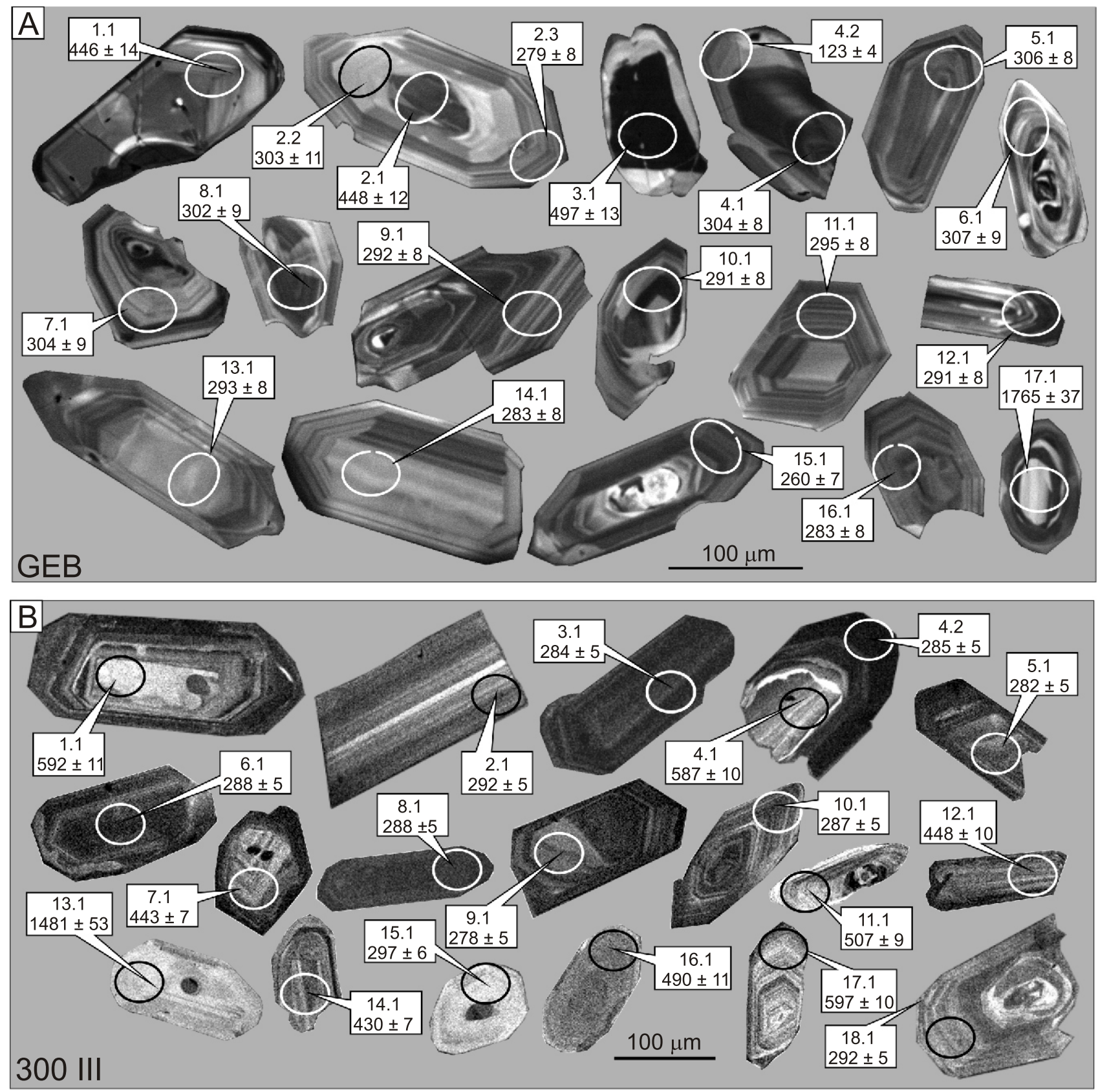

Fig. 15. CL images of zircons

A - from the Gębczyce Bt-Ms granite, sample GEB; B - from the Bt-Ms granite dyke in the Strzelin I Quarry, sample 300 III

The collected results were then processed with the SQUID v1.12 (Ludwig, 2005a) and ISOPLOT/Ex 3.22 (Ludwig, 2005b) software, using the decay constants of Steiger and Jäger (1977). The common lead correction was done using measured ${ }^{204} \mathrm{~Pb}$ according to the model of Stacey and Kramers (1975). The results of the zircon analyses are shown in Appendices 6, 7 and Figures 15-17. Conventionally, the ages given in the text, if not additionally specified, are ${ }^{207} \mathrm{~Pb} /{ }^{206} \mathrm{~Pb}$ ages for zircons older than $650 \mathrm{Ma}$, and ${ }^{206} \mathrm{~Pb} /{ }^{238} \mathrm{U}$ ages for zircons younger than 650 $\mathrm{Ma}$. The errors in the text and tables are given at the 1- $\sigma$ level for individual points, and at 2- $\sigma$ level in Concordia diagrams and for average Concordia ages.
SAMPLE GEB

The zircons of sample GEB (Fig. 15A) are relatively large, with long axes between $\sim 100-200 \mu \mathrm{m}$, normal-prismatic and euhedral. Many of them are broken. In some of the grains, distinct cores are observed (e.g., grains 2, 6, 15 and 17). Typically, the euhedral habit of the crystals imitates the fine "magmatic-type" internal zoning. In a few grains, the internal part is CL dark (3.1). No distinct overgrowths are visible.

Overall, 20 points in 17 zircon grains were analysed (Appendix 6). The SHRIMP results obtained on this sample are not easy to interpret, partly because of apparent instability of the in- 
strument during the analytical session (relatively large analytical errors), and partly because of various discordances of many analytical points. The latter is evidenced by many strongly reversely discordant data points ( $D$ values that vary widely between +645 and $-4000 \%$, Appendix 6 ), though the 2 -sigma error point ellipses overlap the Concordia line (Fig. 16A, B). In spite of the rather poor quality of the results from this sample, the SHRIMP data are presented on diagrams (Fig. 16A, B) and a tentative interpretation is proposed below.

The $U$ and Th contents in the analysed zircons are moderate to high: $U 170-1155$ ppm, Th $58-818$ ppm. The ${ }^{232} \mathrm{Th} /{ }^{238} \mathrm{U}$ ratios are moderate, between 0.23 and $0.73 . \mathrm{Pb}_{\mathrm{c}}$ varies within the range of $0.17-2.3$, with one high value of 9.11 in point 4.2 .

Four points represent inherited zircons: Cl-bright core $1193 \pm 30 \mathrm{Ma}$ (17.1), CL-dark interiors of two crystals $-497 \pm 13$ (3.1) and $448 \pm 12$ (2.1), zoned interior of euhedral crystal (1.1) $-446 \pm 14 \mathrm{Ma}$. In contrast, one point (4.2) is unrealistically young, $123 \pm 4$, indicating strong degrees of radiogenic lead loss.

The main age group of 13 zircons yielded ${ }^{206} \mathrm{~Pb} /{ }^{238} \mathrm{U}$ ages within the range of 283-307 Ma, with a mean of $296 \pm 5 \mathrm{Ma}$ (Fig. 16A). However, the calculated Concordia age of this group has rather high MSWD values, even when excluding four points with relatively large error ellipses (Fig. 16B, all nine points selected): $296 \pm 6 \mathrm{Ma}$, MSWD 6.0, probability of concordance (PoC) 0.015 . Within this group of 9 points, it is possible to distinguish two subgroups:

- older zircons (4 grains shown in red), with Concordia age of $304 \pm 9$ Ma and high MSWD 7.8 and PoC 0.005;

- younger zircons (5 points shown in blue), with Concordia age of $290 \pm 7 \mathrm{Ma}$, MSWD 0.53 and PoC 0.47 .

The 2-sigma point ellipses belonging to the two subgroups overlap, thus, we may interpret the Concordia age of $296 \pm 6$ Ma as the approximate age of magmatic zircon crystallisation in this granite. However, we cannot exclude that the younger zircons of c. 290 (or even 283?) Ma represent the final magmatic stage in this granite, or merely reflect radiogenic lead loss. This dilemma is unresolvable definitely based on the available SHRIMP data from the study sample.

\section{SAMPLE $300 \mathrm{III}$}

The zircons of this sample (Fig. 15B) vary in size, with the long axes between c. 80 and $300 \mu \mathrm{m}$. They are normal-prismatic (combination of the prism and one pyramid) and usually euhedral. In some grains, the internal zonal structure is asymmetrically cut by external faces of the crystals. Many grains are broken.

Most of the zircons show fine "magmatic-type" zonation, and in some of them, distinct irregular cores are visible (e.g., in grains 1.1, 4.1). A few other grains show only a faint internal structure, being both CL-bright $(13.1,15.1)$ and CL-dark (8.1, 16.1). Based on the data obtained, it is difficult to correlate the different ages with particular zircon types.

In this sample, 19 points in 18 grains have been analysed (Appendix 7). The $U$ and Th contents vary from exceptionally low values in one Proterozoic grain 13.1 (U 14 ppm, Th $21 \mathrm{ppm}$ ), through moderate concentrations (U 122-640 and Th $32-283 \mathrm{ppm}$ ) in most of the grains, to very high (U 1009 6640 and Th $85-746 \mathrm{ppm}$ ) in five other analytical points. The ${ }^{232} \mathrm{Th} /{ }^{238} \mathrm{U}$ ratios range between 0.05 and 0.62 (except for the unusually high value of 1.62 in point 13.1). Common lead $\left(\mathrm{Pb}_{\mathrm{c}}\right)$ is low, mostly below $1 \%$, but in six points, it is significantly higher, up to $5 \%$ in point 16.1 .
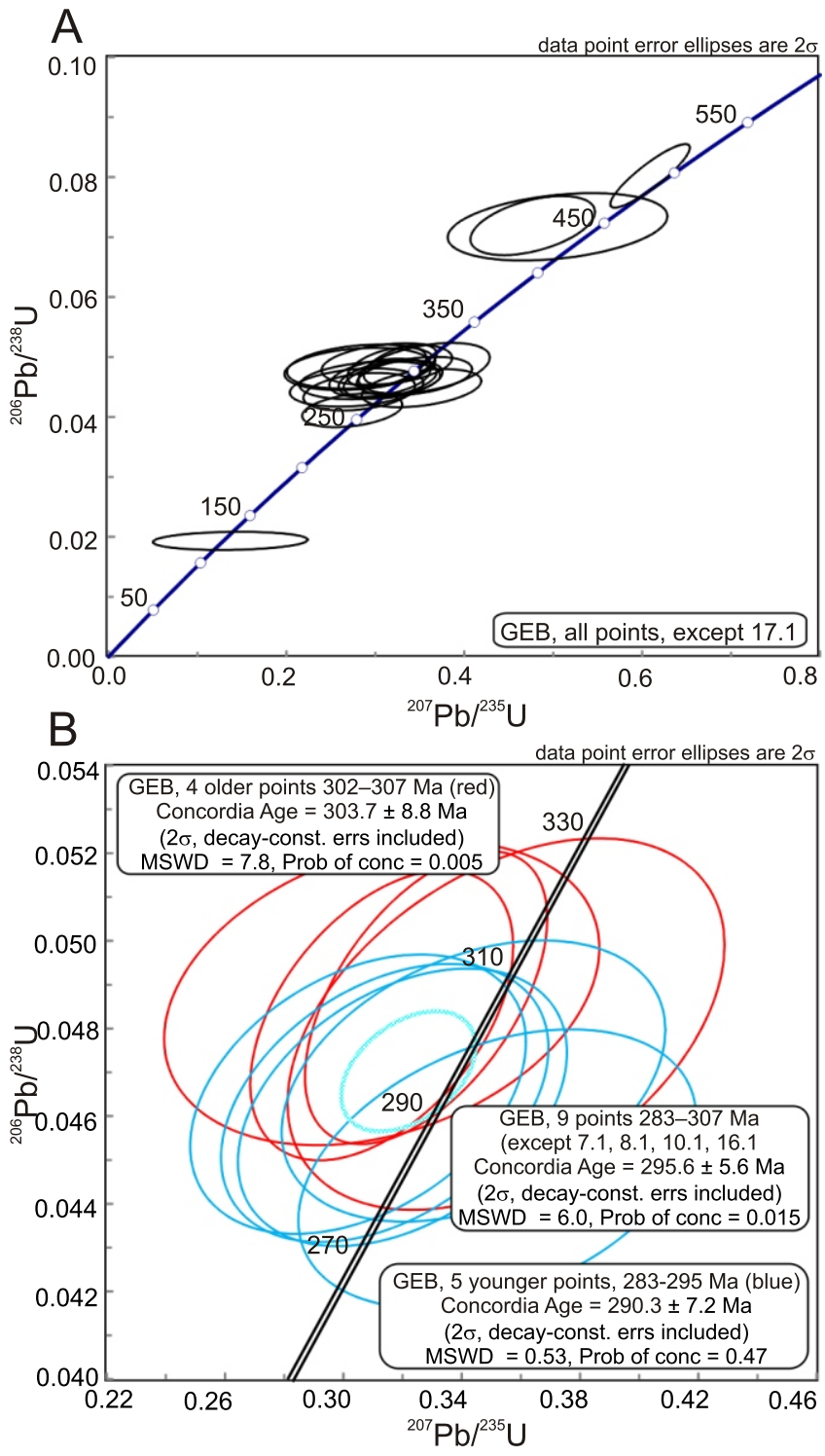

Fig. 16A - Concordia diagram for zircons from the Gębczyce Bt-Ms granite, sample GEB; B - average Concordia age for a group of 9 points is $295.6 \pm 5.6 \mathrm{Ma}$

Two Concordia ages for older $(303.7 \pm 8.8 \mathrm{Ma}, \mathrm{n}=4)$ and younger $(290.3 \pm 7.2 \mathrm{Ma}, \mathrm{n}=5)$ subgroups are shown

The SHRIMP results from all the analysed points (except for the Proterozoic grain 13.1) are shown in the Concordia diagram (Fig. 17A). The calculated discordance $(D=[$ (age $\left.{ }^{207} \mathrm{~Pb} /{ }^{206} \mathrm{~Pb}\right) /\left(\right.$ age $\left.\left.{ }^{206} \mathrm{~Pb} /{ }^{238} \mathrm{U}\right)-1\right]^{* 100}$ ) is usually small to moderate, between -37 to +21 , with three higher values, up to -297 (in 15.1).

Nine points show clearly older ages which can be subdivided into the following four subgroups:

- $1,480 \pm 53 \mathrm{Ma}$ (distinct core in grain 13.1);

- between $587 \pm 10 \mathrm{Ma}$ and $597 \pm 10 \mathrm{Ma}$ (3 points $1.1,4.1$ and 17.1, two of which in cores);

- between $490 \pm 11 \mathrm{Ma}$ and $507 \pm 9 \mathrm{Ma}$ (2 subhedral grains, 11.1 and 16.1 );

- between $430 \pm 7 \mathrm{Ma}$ and $448 \pm 10 \mathrm{Ma}(7.1,12.1,14.1$, all similarly zoned).

The main age population of 10 zircons fall between $278 \pm 5$ and $297 \pm 5 \mathrm{Ma}$ (Fig. 17B). Their Concordia age is $287 \pm 3 \mathrm{Ma}$ 

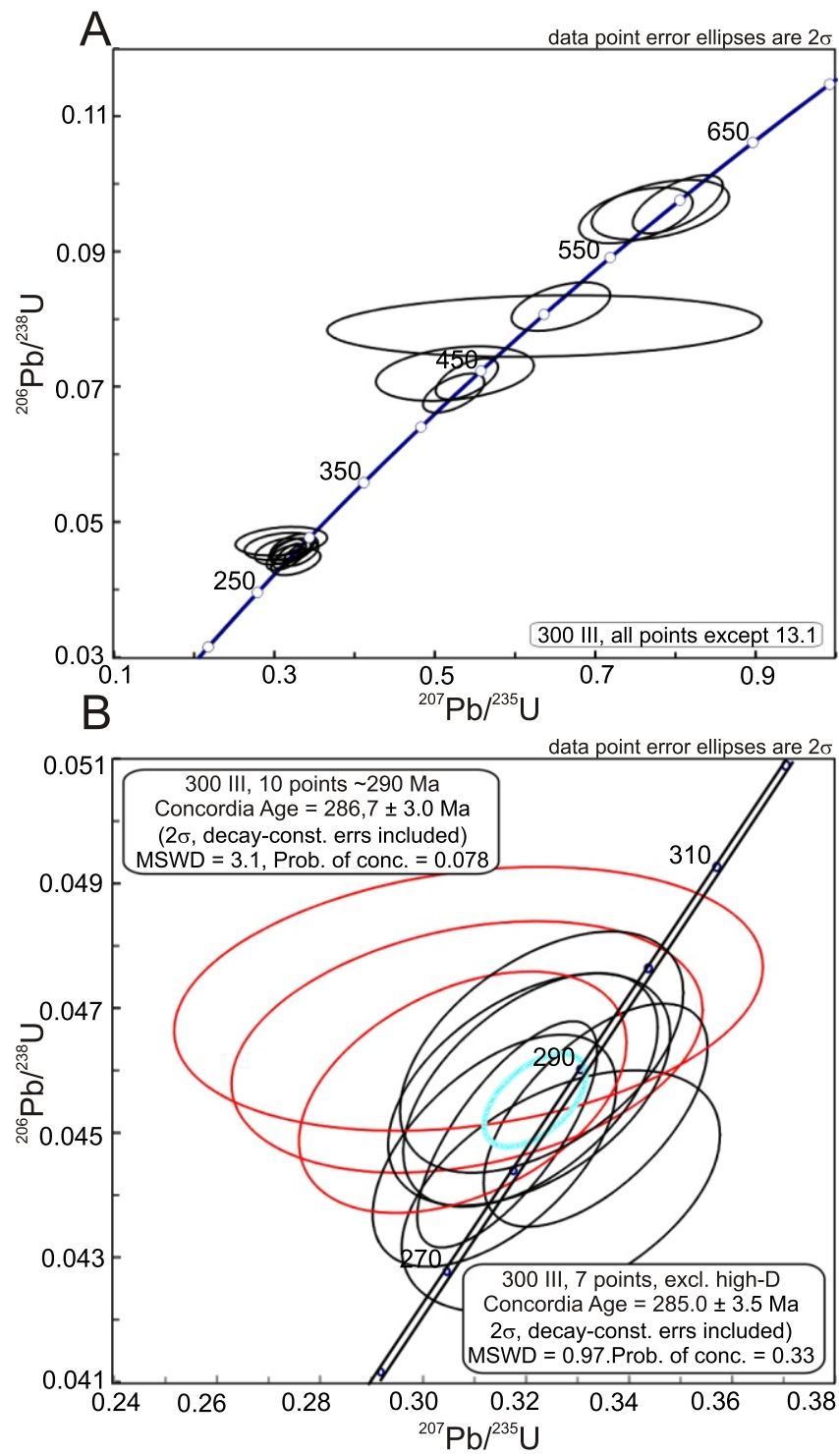

Fig. 17A - Concordia diagram for zircons from the Bt-Ms granite dyke in the Strzelin I Quarry, sample 300 III; B - average Concordia age for a group of 19 points is $286.7 \pm 3 \mathrm{Ma}$

For 7 points, excluding those with somewhat higher discordance $(D)$ indicated in red, the Concordia age is $285.0 \pm 3.5 \mathrm{Ma}$

(2-sigma), with somewhat elevated MSWD of 3.1 and a very low probability of concordance $(\mathrm{PoC}) 0.078$. Excluding three reversely discordant data points of this group, the Concordia age for seven points is $286 \pm 3 \mathrm{Ma}$, with better MSWD of 0.97 and PoC 0.33. This Concordia age, which is also close to the mean ${ }^{206} \mathrm{~Pb} /{ }^{238} \mathrm{U}$ age of $287 \pm 9 \mathrm{Ma}$ for the entire population of 10 points, is considered to reflect the magmatic zircon crystallisation age of this two-mica granite (sample $300 \mathrm{III}$ ) from the dyke in the Strzelin I Quarry.

\section{DISCUSSION}

\section{ZIRCON AGES}

The Concordia age of $296 \pm 6 \mathrm{Ma}$ is interpreted as the magmatic zircon crystallisation age in the Gębczyce Bt-Ms granite.
However, the presence of younger zircons of c. 290 (or even 283) Ma may indicate that the final magmatic stage in this granite took place somewhat later, although the possibility of faint loss of radiogenic $\mathrm{Pb}$ cannot be dismissed. Similar problems in defining the magma crystallisation age have also been met in the medium-grained ( $303 \pm 2 \mathrm{Ma})$ and fine-grained $(283 \pm 8 \mathrm{Ma})$ biotite granites from the Strzelin quarries (Oberc-Dziedzic et al., 2013), in difference to the well-established age of the tonalites from Gęsiniec (295 \pm 3 Ma; Oberc-Dziedzic and Kryza, 2012) and Kalinka (294 \pm 3 Ma; Oberc-Dziedzic et al., 2010). The $296 \pm 6$ Ma zircon age of the Bt-Ms granite from Gębczyce is similar to the age of the Gęsiniec and Kalinka tonalites. Although the ages of the Bt-Ms granites of the Gromnik and Górka Sobocka intrusions have not been determined, their petrological characteristics, similar to those of the Gębczyce granite, suggest that they all belong, similarly as tonalites, to the same, third stage of the Variscan magmatic activity in the Strzelin Massif.

The SHRIMP zircon studies have shown that the Bt-Ms granites from the dykes are, within the analytical errors, of the same age as the granitoids which were cut by the dykes: c. 295 $\pm 3 \mathrm{Ma}$ in the case of the Gęsiniec tonalite (sample GT9) and the corresponding Bt-Ms granite (sample 210; Oberc-Dziedzic and Kryza, 2012), and c. $283 \pm 8$ Ma in the case of the Strzelin biotite granite (Oberc-Dziedzic et al., 2013) and the corresponding Bt-Ms granite dyke of $286 \pm 3$ Ma age (sample $300 \mathrm{III}$ ). Therefore, the host granitoids (Gęsiniec tonalite, and Strzelin biotite granites) and the Bt-Ms granite magmas of the dykes were emplaced in a time span shorter than the (limited) precision of the measured SHRIMP zircon ages. This may indicate that the magmas of different chemical composition, represented by the host granitoids and the Bt-Ms dykes, were generated at broadly the same time and intruded in close proximity.

The age spectra of the inherited zircons in the Bt-Ms granites are similar in all measured samples: GEB, $300 \mathrm{III}$ and 210 (Oberc-Dziedzic and Kryza, 2012). Apart from a few early Proterozoic ages of c. 1.5, 1.2 and $1.0 \mathrm{Ga}$ ), many inherited ages are similar to the ages of zircons from the gneisses of the Strzelin Massif: Strzelin gneiss $-600 \pm 7 \mathrm{Ma}, 568 \pm 7 \mathrm{Ma}$ (Oberc-Dziedzic et al., 2003), Nowolesie gneiss - $602 \pm 7 \mathrm{Ma}$, $587 \pm 4 \mathrm{Ma}$, (Klimas, 2008), $576 \pm 18 \mathrm{Ma}$ (Mazur et al., 2010) and Gościęcice gneiss - $504 \pm 3$ Ma (Oliver et al., 1993), $500 \pm 12 \mathrm{Ma}$ (Mazur et al,. 2010). The inherited zircons may represent crustal components of the Bt-Ms granite magma and indicate that gneisses similar to those exposed in the Strzelin Massif may have been the source material for magmas of all studied granitoid bodies.

The Bt-Ms granite contains also zircons varying in age from 430-448 Ma (Gębczyce and Strzelin Bt-Ms granites). A similar ${ }^{206} \mathrm{~Pb} /{ }^{238} \mathrm{U}$ age of $453 \pm 14 \mathrm{Ma}$ was reported from the Gościęcice gneiss (Mazur et al., 2010) and from the fine-grained granite from the Strzelin Quarry (451 $\pm 9 \mathrm{Ma}$; Oberc-Dziedzic et al., 2013). The geological meaning of these ages is unclear, bearing in mind that they are not based on concordant data points, but are merely ${ }^{206} \mathrm{~Pb} /{ }^{238} \mathrm{U}$ apparent ages, that might simply reflect radiogenic lead loss from significantly older grains.

Zircon age of c. $374 \mathrm{Ma}$ is found in the Gesiniec Bt-Ms granite (Oberc-Dziedzic and Kryza, 2012). Similar ${ }^{206} \mathrm{~Pb} /{ }^{238} \mathrm{U}$ zircon ages of 373-383 Ma were also reported from the fine-grained biotite granite from the Strzelin I Quarry (Oberc-Dziedzic et al., 2013). Such ages were also found in the Sowie Góry migmatites (Kryza and Fanning, 2007) and in xenolith gneiss sampled in the Paszowice basalt from the crust underlying the low-grade metamorphic Kaczawa Unit (Oberc-Dziedzic et al., 
2009). These ages document an important metamorphic/anatectic event in the Central Sudetes.

The presence of inherited zircons in the Bt-Ms granite forming dykes, and their lack in the tonalite (Oberc-Dziedzic and Kryza, 2012) and medium-grained biotite granite from the Strzelin Quarry (Oberc-Dziedzic et al., 2013) suggest that either the biotite-muscovite granite magma did not evolve from the tonalite and biotite granite magma, but originated from separate magma batches, or the magma of the Bt-Ms granite dykes represents a melt evolved from the biotite granite or tonalite magmas which assimilated a zircon-bearing crustal component.

\section{ORIGIN OF THE BIOTITE-MUSCOVITE GRANITE MAGMAS}

The two types of the Bt-Ms granites in the Strzelin Massif (i.e. small plutons and dykes) show some differences in major and trace elements contents (Figs. 12A, C and 13A, C) which imply that the dykes were fed by a more evolved magma than the small plutons. Specifically, all these data suggest that the dykes were fed by a residual melt left behind after the fractionation of a crystal assemblage of Fe-Mg minerals, plagioclase, and accessory phases (Fe-Ti oxides, zircon, LREE-rich phosphates). These differences, however, might be, at least in part, inherited from the source materials. In the latter case, the granite magma of the small plutons would have originated from a slightly more basic source than the magma forming the dykes. It is also possible that the sources of the magma in the plutons and in the dykes were similar, but either the former contained some mantle-derived components, or the magma of the dykes was contaminated by crustal materials.

The granites of the small plutons show lower values of ${ }^{87} \mathrm{Sr}^{86} \mathrm{Sr}_{\mathrm{i}}=295 \mathrm{Ma}(0.7088-0.7104)$ and higher values of $\varepsilon \mathrm{Nd}_{295}$ $(-4.5,-4.8)$, in comparison with ${ }^{87} \mathrm{Sr}^{86} \mathrm{Sr}_{\mathrm{i}}=286 \mathrm{Ma}(0.7191-7260)$ and the $\varepsilon \mathrm{Nd}_{286 \mathrm{Ma}}(-5.4,-5.7,-5.9)$ values obtained from the dykes (Tables 3 and 4), suggesting their derivation from different sources. The lower $\varepsilon N d$ values in the dykes reflect a slightly more "crustal" signature, that is to say, a slightly greater contribution of a crustal end-member, possibly by local assimilation shortly before igneous emplacement. The low volume of magmas such as those of the dykes would, indeed, be more sensitive to such "contamination" than the bulk of the igneous bodies that formed in the lower crust. The difference between $\varepsilon \mathrm{Nd}$ values of the dyke-forming Bt-Ms granites and their host granitoids (Gęsiniec tonalite: -5.9 and -4.0 , and -2.8 , respectively; Strzelin biotite granite: -5.4 and -5.7 , and -3.8 , respectively) is even greater than between the Bt-Ms granites of the dykes and of the small plutons: $-5.4,5.7,-5.9$ and $-4.5,-4.9$, respectively (Table 4). Because the granites of the dykes are relatively late-stage compared to the bulk of the intrusions, their origin might well have been connected with the assimilation of an upper crustal component, which occurred during fractional crystallisation (AFC). The anomalously elevated values of ${ }^{147} \mathrm{Sm} /{ }^{144} \mathrm{Nd}$ ratios of the two samples from the Strzelin I Quarry (STIN 1, STIN 2; Table 4) provide circumstantial evidence for fractionation of a LREE-enriched phase (likely, monazite) and supports an origin of these dykes as evolved, fractionated residual melts having evolved in an open system. The very radiogenic $\mathrm{Sr}$ isotope signature of these two samples also requires the introduction of ${ }^{87} \mathrm{Sr}$-enriched partial melts or fluids from the surrounding crust. In this scenario, STIN 2 - with a higher value of $\mathrm{Rb} / \mathrm{Sr}$ and higher ${ }^{87} \mathrm{Sr}^{86} \mathrm{Sr}_{286 \mathrm{Ma}}$ - would be more "evolved" than STIN 1, as far as Sr isotopes are concerned, but the fact that these two samples do not have the same $\left({ }^{87} \mathrm{Sr}^{86} \mathrm{Sr}_{286 \mathrm{Ma}}\right)$ shows that they were not isotopically homogeneous at $\sim 286 \mathrm{Ma}$, that is, assimilated variable amounts of the crustal component or crustal materials that were isotopically heterogeneous. Moreover, for these two samples, there is no obvious correlation between $\mathrm{Sr}$ isotopes and $\varepsilon \mathrm{Nd}$ values. This decoupling may be interpreted to reflect the involvement of hydrous fluids derived from the local upper crust, because such fluids can be highly enriched in radiogenic $\mathrm{Sr}$, and very poor in $\mathrm{Nd}$ (as a reflection of the contrasting solubilities of these elements in $\mathrm{H}_{2} \mathrm{O}$ ).

Some information concerning the source material of the Bt-Ms granites is recorded in the zircons. In contrast to the Strzelin medium-grained biotite granite and the Gęsiniec tonalite in which older zircon populations are absent, because they were dissolved during the magma-generating processes (Oberc-Dziedzic et al., 2013), the Bt-Ms granites, similarly as the Strzelin fine-grained biotite granite, abound in inherited zircons of various ages, typically observed in zircons from gneisses of the Strzelin Massif. This strongly suggests that similar gneisses were the source material for, or at least contributed to, the magma of the Bt and Bt-Ms granites. However, such gneisses were not the unique source material for granites. The ¿Nd values of the 602-568 Ma old gneisses from the Strzelin Massif calculated as they were $300 \mathrm{Ma}$ old, at the approximate time of the late stage of Variscan granite emplacement, are considerably lower $\left(\varepsilon \mathrm{Nd}_{300} \mathrm{Ma}\right.$ from -14 to -16 , unpublished data) than the Bt-Ms granites $(-4.5$ to -5.9$)$. Therefore, the ${ }_{\varepsilon} \mathrm{Nd}_{300 \mathrm{Ma}}$ data reinforce the conclusion that these gneisses could contribute only quite marginally to the production of the Variscan granitoids which display much more radiogenic $\mathrm{Nd}$ isotope signatures. If these gneisses were indeed involved, a major contribution of relatively (isotopically) primitive sources is required, such as c. 300 Ma old mantle-derived magmas. Another possibility is that the Variscan granitoids were derived from more mafic (with higher time-integrated Sm/Nd ratios) lower crustal materials.

\section{CRYSTALLISATION OF THE BIOTITE-MUSCOVITE GRANITE MAGMAS}

The zirconium concentrations in the Bt-Ms granites of the small plutons (Gębczyce and Górka Sobocka - 113-137 ppm, excluding the Gromnik granite - $181 \mathrm{ppm}$ ) and of the granite dykes (58-64 ppm) are typical of inheritance-rich granitoids (80-150 ppm; Miller et al., 2003). The Zr concentrations of the host biotite granites, tonalites and diorites (167-597 ppm) are in the range of inheritance-poor intrusions (200-800 ppm; Appendix 5).

The calculated $\mathrm{T}_{\mathrm{Zr}}$ of $765-779^{\circ} \mathrm{C}$ for the Gębczyce and Górka Sobocka granites, and $706-720^{\circ} \mathrm{C}$ for the granites of the dykes may be interpreted as broadly approximating the initial magma temperature at the source (Miller et al., 2003). $T_{Z r}$ values for intrusions with little or no inheritance, such as the Strzelin biotite granites, tonalites and diorites $\left(747-867^{\circ} \mathrm{C}\right.$, Appendix 5), are lower than predicted by Miller et al. (2003) for inheritance-poor granitoids (a mean of $837^{\circ} \mathrm{C}$ ). The discrepancy between the calculated temperature of magma and the lack of inheritance in the granitoid rocks suggests that the zircon saturation temperatures not always provide proper information about the temperatures at which these granitoids formed (Chappell et al., 2004).

The inheritance-rich granites of the small plutons (Gromnik, Gębczyce, Górka Sobocka) may be classified as "cold granites" (Miller et al., 2003), which were interpreted as formed at temperatures too low for dehydration melting, and probably required fluid influx to trigger partial melting. The Bt-Ms granites from the dykes are also of the inheritance-rich cold granite type. However, they show close age and spatial links with their host 
granitoids' inheritance-poor "hot" biotite granites and tonalite-diorites which may form through dehydration melting and, as produced in the crust, require a substantial transient heat flux (Miller et al., 2003). Supposedly, the Bt-Ms granites of the dykes represent late-stage residual magmas - the "tail" of the liquid line of descent - which became peraluminous through fractionation and assimilated crustal materials containing zircons which were not dissolved because of the peraluminous magma composition and because of the relatively low temperature. In this model, the old zircons correspond to xenocrysts and not to grains inherited from the major, lower crustal source of the bulk of the magma.

The changes of the An content in plagioclases, from relatively low in the clear grains interior, followed by the elevated An content in the etched ring and, again, lower content in the clear external rim showing normal zoning, indicate a changing chemical composition of magma in the early stage of crystallisation. This might document mingling with relatively mafic magmas at an earlier stage. The second generation of plagioclases is more acidic, normally zoned or without zoning, and contain usually rounded quartz grains.

Among differences between the studied bodies of the Bt-Ms granites is the presence of the cotectic cordierite in granites forming the dykes, and its lack in the granites of the small plutons (the Gębczyce Pluton is the exception). The nucleation of cordierite in the magmatic cotectic environment is conditioned by $\mathrm{T}, \mathrm{P}$ and, reaching an appropriate chemical composition, favoured by high $\mathrm{A} / \mathrm{CNK}$, high $\Sigma\left(\mathrm{Mg}+\mathrm{Fe}^{2+}\right)$ and generally low $f_{\mathrm{H} 2 \mathrm{O}}($ Clarke, 1995). The A/CNK ratio is similar in all granites, and $\Sigma\left(\mathrm{Mg}+\mathrm{Fe}^{2+}\right)$ is considerably higher in the plutons (including the Gębczyce granite) than in the dykes. The presence of cordierite in the Gębczyce granite and in the granites of the dykes suggests that the chemical conditions for crystallization of cordierite were fulfilled in all granites studied, in spite of the chemical differences between them. If so, the different mineral composition of the Bt-Ms granites depends on the amount of water: the cordierite-bearing and micas-poor granites of the dykes and of the Gębczyce Pluton would represent relatively "dry" magmas, whereas the Gromnik and Górka Sobocka granites, rich in biotite and muscovite but not containing cordierite, would represent more "wet" magmas (Table 1).

Cordierite, forming cloths in the granite dykes and nodules in the Gębczyce granite, is associated with etched plagioclases and rounded quartz grains, but not with K-feldspar. According to Huang and Wyllie (1973), quartz followed by plagioclase is the first phase which crystallises under initially $\mathrm{H}_{2} \mathrm{O}$-undersaturated conditions. This implies that cordierite, coexisting with quartz and plagioclase, represents the early stage of granite crystallisation, prior to saturation in an aqueous vapour phase. Magmas become saturated during ascent and a decrease of pressure (Johannes and Holtz, 1996) or during crystallisation at low pressure in the magma chamber. The residual, water saturated magmas collect at the top of the magma chamber. A fluid overpressure generated near the roof of the magma chamber may cause fracturing of the roof and, as a result, sudden reduction in the solubility of water in the magma, and brings about a pressure quench (Flood and Shaw, 2014). The pressure-quench mechanism is suggested to be responsible for the genesis of the cordierite nodules in the Gębczyce granite. The next stage of solidification comprised crystallisation of micas, anhedral plagioclase richer in Ab component, K-feldspar and quartz, the latter forming, apart from individual grains, also overgrowths with K-feldspar and rounded inclusions in feldspars. Later, under subsolidus conditions, the activity of the $\mathrm{K}$-aqueous fluids caused the transformation of cordierite into green biotite and muscovite. The post-magmatic fluids were responsible for the origin of the secondary muscovite, chloritization of biotite, removing part of $\mathrm{Ti}$ from biotite and a disturbance of the REE system visible as the tetrad effect (Irber, 1999).

\section{CONCLUSIONS}

1. In the Strzelin Massif, the Bt-Ms granites of Gromnik, Gębczyce and Górka Sobocka form small plutons, located along the same fault. The Bt-Ms granites form also dykes both within metamorphic country-rocks, and in tonalites and biotite granites of the massif.

2. The studied Bt-Ms granites show some petrographic variation, e.g. the presence of cotectic cordierite and the low content of micas in the granites from the dykes (and in the Gębczyce small pluton), when compared with the granites of the Gromnik and Górka Sobocka plutons. The pressure-quench mechanism is suggested as responsible for the formation of cordierite nodules in the Gębczyce granite. The observed differences in mineral composition reflect various amounts of water available at the time of magma genesis: the granites from the dykes and from the Gębczyce Pluton correspond to relatively "dry" magmas, whereas those from Gromnik and Górka Sobocka derived from more "wet" magmas.

3. The $\mathrm{T}_{\mathrm{Zr}}$ calculated for the Bt-Ms granites of the plutons $\left(765-801^{\circ} \mathrm{C}\right)$ and of the dykes $\left(706-720^{\circ} \mathrm{C}\right)$ can be interpreted as the "initial magma temperature" at the source or the temperature prevailing at the time of zircon crystallisation.

4. The Bt-Ms granites of the small plutons show lower values of ${ }^{87} \mathrm{Sr}^{86} \mathrm{Sr}_{\mathrm{i}=295 \mathrm{Ma}}(0.7088-0.7104)$ and higher values of the $\varepsilon_{2 d_{295}}(-4.5,-4.8)$, in comparison with the values for the granites of the dykes, which suggests the derivation of the former from an "isotopically less evolved" crustal source (that is, a source with a lower time-integrated LREE-enrichment).

5. The Bt-Ms granites from the small plutons (Gębczyce granite of $296 \pm 6 \mathrm{Ma}$ ) and the Gesiniec and Kalinka tonalites (c. $295 \mathrm{Ma}$ ) belong to the same, third stage of magmatic activity in the Strzelin Massif. The Bt-Ms granites from the dykes are, within error, of very similar ages as their host granitoids, i.e.: C. $295 \mathrm{Ma}$ in the case of the Gęsiniec tonalite and the enclosed Bt-Ms granite, and $283 \pm 8 \mathrm{Ma}$ in the case of the Strzelin biotite granite and $286 \pm 3 \mathrm{Ma}$ of its Bt-Ms granite dyke. This strongly suggests that the magmas of different chemical composition, represented by the host granitoids and Bt-Ms dykes, were generated at broadly the same time and intruded in close proximity.

6. In keeping with their peraluminous compositions, the Bt-Ms granites abound in old (inherited or xenocrystic) zircons. Their age spectra are similar in all measured samples, and typical of the gneisses of the Strzelin Massif. This indicates that source materials similar in age to the gneisses exposed in the Strzelin Massif could have contributed to the production of the Bt-Ms granite parental magmas. However, $\mathrm{Nd}$ isotope data clearly require an important contribution of isotopically less mature components. This process might either have occurred in the pre-existing lower crustal source, or the less mature materials have been emplaced as mantle-derived mafic magmas at the time of partial melting, or both. 
Acknowledgements. We thank K. Dymna for zircon separation. P. Dzierżanowski and L. Jeżak are acknowledged for their help and assistance with EMP analyses. Dr. hab. A. Gawęda, Prof. W. Siebel and Prof. J. Wiszniewska are thanked for their detailed and constructive reviews. The investigations were performed within the Project N307 008 32/0314 of the Pol- ish Ministry of Science and Education. Additional support came from internal grants 1017/S/ING and 2022/W/ING of the University of Wrocław.

\section{REFERENCES}

Badura, J., 1979. Szczegółowa Mapa Geologiczna Sudetów, arkusz Stolec 1:25 000 (in Polish). Wyd. Geol., Warszawa.

Bereś, B., 1969. Petrography of granite of the environments of Strzelin (in Polish with English summary). Archiwum Mineralogiczne, 28: 5-105.

Białek, D., 2014. SHRIMP U-Pb zircon geochronology of the Jawornik granitoids (West Sudetes, Poland). Geologia Sudetica, 42: 4

Black, L.P., Kamo, S.L., Allen, C.M., Aleinikoff, J.N., Davis, D.W., Korsch, R.J., Foudoulis, C., 2003. TEMORA 1: a new zircon standard for Phanerozoic U-Pb geochronology. Chemical Geology, 200: 155-170.

Chappell, B.W., White, A.J.R., Williams, I.S., Wyborn, D., 2004. Low- and high-temperature granites. Transactions of the Royal Society of Edinburgh: Earth Sciences, 95/1-2: 125-140.

Clarke, D.B., 1995. Cordierite in felsic igneous rocks: a synthesis. Mineralogical Magazine, 59: 311-325.

De Paolo, J., 1981a. Neodymium isotopes in the Colorado Front Range and crust - mantle evolution in the Proterozoic. Nature, 291: 193-196.

De Paolo, J., 1981b. A Nd and Sr isotopic study of Mesozoic calc-alkaline batholiths of the Sierra Nevada and Peninsular Ranges, California. Journal of Geophysical Research, 86: 10370-10488.

Flood, R.H., Shaw, S.E., 2014. Microgranitoid enclaves in the felsic Looanga monzogranite, New England Batholith, Australia: Pressure quench cumulates. Lithos, 198-199: 92-102.

Frost, B.R., Barnes, C.G., Collins, W.J., Arculus, R.J., Ellis, D.J., Frost, C.D., 2001. A geochemical classification for granitic rocks. Journal of Petrology, 11: 2033-2048.

Haskin, L.A., Haskin, M.A., Frey, F.A., Wildman, T.R., 1968. Relative and absolute terrestrial abundances of the rare earths. In: Origin and Distribution of the Elements (ed. L.H. Ahrens), Pergamon, Oxford, 1: 889-911.

Huang, W.L., Wyllie, P.J., 1973. Melting relations of muscovite granite to $35 \mathrm{kbar}$ as a model for fusion metamorphosed subducted oceanic sediments. Contributions to Mineralogy and Petrology, 42: 1-14.

Irber, W., 1999. The lanthanide tetrad effect and its correlation with $\mathrm{K} / \mathrm{Rb}, \mathrm{Eu} / \mathrm{Eu}^{*}, \mathrm{Sr} / \mathrm{Eu}, \mathrm{Y} / \mathrm{Ho}$, and $\mathrm{Zr} / \mathrm{Hf}$ of evolving peraluminous granite suites. Geochimica et Cosmochimica Acta, 63: 489-508.

Johannes, W., Holtz, F., 1996. Petrogenesis and Experimental Petrology of Granitic Rocks. Springer, Berlin.

Klimas, K., 2008. Geochronology and petrogenetical study of zircons from selected crystalline rocks in the eastern part of the Fore-Sudetic Block (in Polish with English summary). Uniwersytet Wrocławski, Instytut Nauk Geologicznych, Wrocław.

Klimas, K., Kryza, R., Fanning, C.M., 2009. Palaeo- to Mesoproterozoic inheritance and Ediacaran anatexis recorded in gneisses at the NE margin of the Bohemian Massif: SHRIMP zircon data from the Nowolesie gneiss, Fore-Sudetic Block (SW Poland). Geologia Sudetica, 41: 25-40.

Kryza, R., Fanning, C.M., 2007. Devonian deep-crustal metamorphism and exhumation in the Variscan Orogen: evidence from SHRIMP zircon ages from the HT-HP granulites and migmatites of the Góry Sowie (Polish Sudetes). Geodinamica Acta, 20: 159-175.

Kryza, R., Crowley, Q.G., Larionov, A., Pin, C., Oberc-Dziedzic, T., Mochnacka, K., 2012. Chemical abrasion applied to SHRIMP zircon geochronology: an example from the Variscan Karkonosze Granite (Sudetes, SW Poland). Gondwana Research, 21: 757-767.

Kryza, R., Schaltegger, U., Oberc-Dziedzic, T., Pin, C. Ovtcharova, M., 2014a. Geochronology of a composite granitoid pluton: a high-precision ID-TIMS U-Pb zircon study of the Variscan Karkonosze Granite (SW Poland). International Journal of Earth Sciences, 103: 683-696.

Kryza, R., Pin, C., Oberc-Dziedzic, T., Crowley, Q.G., Larionov, A., 2014b. Deciphering the geochronology of a large granitoid pluton (Karkonosze Granite, SW Poland): an assessment of $\mathrm{U}-\mathrm{Pb}$ zircon SIMS and $\mathrm{Rb}-\mathrm{Sr}$ whole-rock dates relative to $\mathrm{U}-\mathrm{Pb}$ zircon CA-ID-TIMS. International Geology Review, 56: 756-782.

Larionov, A.N., Andreichev, V.A., Gee, D.G., 2004. The Vendian alkaline igneous suite of northern Timan: ion microprobe $\mathrm{U}-\mathrm{Pb}$ zircon ages of gabbros and syenite. Geological Society of London Memoirs, 30: 69-74.

Laurent, A., Janoušek, V., Magna, T., Schulmann, K., Miková, J., 2014. Petrogenesis and geochronology of a post-orogenic calc-alkaline magmatic association: the Žulová Pluton, Bohemian Massif. Journal of Geosciences, 59: 415-440.

Lorenc, M.W., 1987. Cordierite in granitoid rocks of Hercynian massifs of the Central System (Extremadura, Spain and Strzelin (Lower Silesia) - a preliminary comparative study (in Polish with English summary). Annales Societatis Geologorum Poloniae, 57: 89-106.

Ludwig, K.R., 2005a. SQUID 1.12 A User's Manual. A Geochronological Toolkit for Microsoft Excel. Berkeley Geochronology Center Special Publication: 1-22, http://www.bgc.org/klprogrammenu.html

Ludwig, K.R., 2005b. User's Manual for ISOPLOT/Ex 3.22. A Geochronological Toolkit for Microsoft Excel. Berkeley Geochronology Center Special Publication: 1-71, http://www.bgc.org/klprogrammenu.html.

Mazur, S., Kröner, A., Szczepański, J., Turniak, K., Hanžl, P. Melichar, R., Rodionov, N.V., Paderin, I., Sergeev, S.A., 2010. Single zircon $\mathrm{U}-\mathrm{Pb}$ ages and geochemistry of granitoid gneisses from SW Poland: evidence for an Avalonian affinity of the Brunian microcontinent. Geological Magazine, 147: 508-526.

Miller, C.F., Stoddard, E.F., Bradfish, L.J., Dollase, W.A., 1981 Composition of plutonic muscovite: genetic implications. Canadian Mineralogist, 19: 25-34.

Miller, C.F., Meschter, McDowell, S., Mapes, R.W., 2003. Hot and cold granites? Implications of zircon saturation temperatures and preservation of inheritance. Geology, 31: 529-532.

Morawski, T., Kościówko, H., 1975. Granity rejonu Strzelina i ich kontakty (in Polish). Przewodnik 47 Zjazdu Polskiego Towarzystwa Geologicznego, Warszawa: 181-183.

Nakamura, N., 1974. Determination of REE, Ba, Fe, Mg, Na and K in carbonaceous and ordinary chondrites. Geochimica et Cosmochimica Acta, 38: 757-775.

Oberc, J., 1966. Geology of crystalline rocks of the Wzgórza Strzelińskie Hills, Lower Silesia (in Polish with English summary). Studia Geologica Polonica, 20: 1-187. 
Oberc, J., Oberc-Dziedzic, T., Klimas-August, K., 1988. Geological map of the Strzelin Hills $(1: 25,000)$ (in Polish) (ed. J. Oberc). Instytut Nauk Geologicznych Uniwersytetu Wrocławskiego, Przedsiębiorstwo Geologiczne Wrocław.

Oberc-Dziedzic, T., 1991. Geological setting of the Strzelin granitoids (in Polish with English summary). Acta Universitatis Wratislaviensis, 1375, Prace Geologiczno-Mineralogiczne, 29: 295-324.

Oberc-Dziedzic, T., Kryza, R., 2012. Late stage Variscan magmatism in the Strzelin Massif (SW Poland): SHRIMP zircon ages of tonalite and Bt-Ms granite of the Gęsiniec intrusion. Geological Quarterly, 56 (2): 225-236.

Oberc-Dziedzic, T., Madej, S., 2002. The Variscan overthrust of the Lower Palaeozoic gneiss unit on the Cadomian basement in the Strzelin and Lipowe Hills massifs, Fore-Sudetic Block, SW Poland; is this part of the East-West Sudetes boundary? Geologia Sudetica, 34: 39-58.

Oberc-Dziedzic, T., Pin, C., 2000. The granitoids of the Lipowe Hills (Fore-Sudetic Block) and their relationship to the Strzelin granites. Geologia Sudetica, 33: 17-22.

Oberc-Dziedzic, T., Pin, C., Duthou, J.L., Couturie, J.P., 1996 Age and origin of the Strzelin granitoids (Fore-Sudetic Block Poland): ${ }^{87} \mathrm{Rb} /{ }^{86} \mathrm{Sr}$ data. Neues Jahrbuch für Mineralogie Abhandlungen, 171: 187-198.

Oberc-Dziedzic, T., Kryza, R., Klimas, K., Fanning, M.C., 2003. SHRIMP U/Pb zircon geochronology of the Strzelin gneiss, SW Poland: evidence for a Neoproterozoic thermal event in the Fore-Sudetic Block, Central European Variscides. International Journal of Earth Sciences, 92: 701-711.

Oberc-Dziedzic, T., Kryza, R., Klimas, K., Fanning, M.C., Madej, S., 2005. Gneiss protolith ages and tectonic boundaries in the NE part of the Bohemian Massif (Fore-Sudetic Block, SW Poland). Geological Quarterly, 49 (4): 363-378.

Oberc-Dziedzic, T., Kryza, R., Pin, C., 2009. The crust beneath the Polish Sudetes: evidence from a gneiss xenolith in Tertiary basanite from Paszowice. Geodinamica Acta, 22: 165-187.

Oberc-Dziedzic, T., Kryza, R., Białek, J., 2010. Variscan multistage granitoid magmatism in Brunovistulicum: petrological and SHRIMP U/Pb zircon geochronological evidence from the southern part of the Strzelin Massif, SW Poland. Geologica Quarterly, 54 (3): 301-324.

Oberc-Dziedzic, T., Kryza, R., Pin, C., Madej, S., 2013. Variscan granitoid plutonism in the Strzelin Massie (SW Poland): petrology and age of the composite Strzelin intrusion. Geologica Quarterly, 57 (2): 269-288.

Oberc-Dziedzic, T., Kryza, R., Pin, C., 2015. Variscan granitoids related to shear zones and faults: examples from the Central Sudetes (Bohemian Massif) and the Middle Odra Fault Zone. International Journal of Earth Sciences, 104: 1139-1166.

Oliver, G.J.H., Corfu, F., Krough, T.E., 1993. U-Pb ages from SW Poland: evidence for a Caledonian suture zone between Baltica and Gondwana. Journal of the Geological Society, 150 : 355-369.

Pietranik, A., Koepke, J., 2009. Interactions between dioritic and granodioritic magmas in mingling zones: plagioclase record of mixing, mingling and subsolidus interactions in the Gęsiniec Intrusion, NE Bohemian Massif, SW Poland. Contributions to Mineralogy and Petrology, 158: 17-36.

Pietranik, A., Waight, T., 2008. Processes and sources during Late Variscan dioritic-tonalitic magmatism: insights from plagioclase chemistry (Gęsiniec Intrusion, NE Bohemian Massif, Poland). Journal of Petrology, 49: 1619-1645.

Pin, C., Santos Zalduegui, J.F., 1997. Sequential separation of light rare earth elements, thorium and uranium by miniaturized extraction chromatography: application to isotopic analyses of silicate rocks. Analytica Chimica Acta, 339: 79-89.

Rudnick, R.J., Gao, S., 2005. Composition of the continental crust. In: The Crust (ed. R.J. Rudnick), Vol. 3 Treatise on Geochemistry (eds. H.D. Holland and K.K. Turekian). Elsevier - Pergamon, Oxford.

Stacey, J.S., Kramers, J.D., 1975. Approximation of terrestrial lead isotope evolution by a two-stage model. Earth and Planetary Science Letters, 26: 207-221.

Steiger, R.H., Jäger, E., 1977. Subcommission on geochronology convention on the use of decay constants in geo- and cosmochronology. Earth and Planetary Science Letters, 36 359-362.

Suess, F.E., 1926. Intrusionstektonik und Wandertektonik im variszischen Gebirge. Borntraeger, Berlin.

Thompson, R.N., 1982. British Tertiary volcanic province. Scottish Journal of Geology, 18: 49-107.

Turniak, K., Mazur, S., Wysoczanski, R., 2000. SHRIMP zircon geochronology and geochemistry of the Orlica-Śnieżnik gneisses (Variscan belt of Central Europe) and their tectonic implications. Geodinamica Acta, 13: 1-20.

Turniak, K., Tichomirowa, M., Bombach, K., 2006. Pb-evaporation zircon ages from the Strzelin Massif (SW Poland). Mineralogical Society of Poland Special Papers, 29: 212-215.

Turniak, K., Mazur, S., Domańska-Siuda, J., Szuszkiewicz, A., 2014. SHRIMP U-Pb zircon dating for granitoids from the Strzegom-Sobótka Massif, SW Poland: constrains on the initial time of Permo-Mesosoic lithosphere thinning beneath Central Europe. Lithos, 208-209: 415-429.

Vernon, R.H., 2004. A Practical Guide to Rock Microstructure. Cambridge University Press.

Watson, E.B., Harrison, T.M., 1983. Zircon saturation revisited: Temperature and composition effects in a variety of crustal magma types. Earth and Planetary Science Letters, 64: 295-304.

Whitney, D.L., Evans, B.W., 2010. Abbreviations for names of rock-forming minerals. American Mineralogist, 95: 185-187.

Wiedenbeck, M., Allé, P., Corfu, F., Griffin, W.L., Meier, M. Oberli, F., Von Quadt, A., Roddick, J.C., Spiegel, W., 1995. Three natural zircon standards for U-Th-Pb, Lu-Hf, trace element and REE analyses. Geostandards Newsletter, 19: 1-23.

Williams, I.S., 1998. U-Th-Pb Geochronology by ion microprobe. In: Applications in microanalytical techniques to understanding mineralizing processes. Reviews in Economic Geology, 7: 1-35.

Wojnar, B., 1977. The petrography of granite of Górka Sobocka (Fore-Sudetic block) (in Polish with English summary). Acta Universitatis Wratislaviensis, 378, Prace Geologiczno-Mineralogiczne, 6: 139-156.

Wójcik, L., 1968. Szczegółowa Mapa Geologiczna Sudetów, arkusz Ciepłowody 1:25 000. Wyd. Geol., Warszawa.

Wroński, J., 1973. Szczegółowa Mapa Geologiczna Sudetów, arkusz Ziębice 1:25 000. Wyd. Geol., Warszawa

Žák, J., Verner, K., Sláma, J., Kachlík, V., Chlupáčová, M, 2013. Multistage magma emplacement and progressive strain accumulation in the shallow-level Krkonoše-Jizera plutonic complex, Bohemian Massif. Tectonics, 32: 1493-1512. 